\title{
Dios revela el Reino a los pobres*
}

\section{Pedro Trigo, Centro Gumilla, Caracas}

\section{Introducción}

Acepto este título que me otorgan con tanta generosidad, confundido porque soy consciente de lo modesto de mis aportes, agradecido porque me lo otorgan ustedes, la comunidad de la Universidad Iberoamericana de Puebla, que desde la primera vez que me invitaron, me acogieron con tanta calidez, cercanía e inteligencia como solo ustedes pueden hacerlo. Agradecido porque los estimo como una comunidad empeñosa, cualificada, dinámica, capaz de trabajar en equipo, consciente de sus responsabilidades con el país y solidaria con los de abajo. Lo acepto, sobre todo, alegre porque es un homenaje a la teología latinoamericana.

Hoy, la teología latinoamericana no está de moda. Hoy, las élites tienden a mirar al Primer Mundo y, en su caso, al norte. Hoy, esta teología se ve como una interferencia inoportuna y por eso se busca afanosamente pasar esa página que tanto revuelo causó. Por eso, en esta ciudad que pugna por subirse al carro de la globalización, aunque sea apendicularmente, este homenaje a la teología latinoamericana marca una dirección trascendente. No somos unos tirapiedras ni pretendemos una postura meramente testimonialista. Buscamos una mundialización alternativa que integre la última revolución tecnológica a un proyecto en que quepan todos los pueblos del mundo con sus respectivas culturas, y en concreto nuestros pueblos con sus culturas en un estado de justicia e interacción simbiótica. Para nosotros, los cristianos, ese es el proyecto de Dios para nuestro mundo, un proyecto que se trasciende en una verdadera fraternidad, la de las hijas e hijos de Dios, en Jesús de Nazaret, su Hijo único y el Hermano universal.

* Discurso pronunciado por Pedro Trigo con motivo del Doctorado Honoris Causa en Cristología Latinoamericana que le fue conferido por la Universidad Iberoamericana de Puebla, México, en septiembre de 2010. 
Eso representa la teología latinoamericana y eso es lo que han querido reconocer a través de mí, que, aunque modestamente, he estado participando en ella desde el principio. Por eso recibo con alegría este doctorado, que es un nuevo motivo de compromiso. Y se lo agradezco de todo corazón.

Como la disertación que acompaña a este conferimiento debe expresar su sentido, he escogido una frase del Evangelio que puede sonar desafiante, pero que encierra una advertencia y, más aún, una invitación que todos los que estamos aquí, empezando por mí, estamos llamados a aceptar como una buena noticia. Es una oración de Jesús y dice así:

Te bendigo, Padre, Señor de cielos y tierra,

porque has ocultado estas cosas a los sabios y entendidos

y se las has revelado a la gente sencilla.

(Lc 10, 21; Mt 11,25)

Jesús no era un sujeto que se dedicaba a proferir dichos provocativos sin contenido analítico para escandalizar y en el fondo para deslumbrar a la gente, haciéndose fama de estar por encima del vulgo. Jesús no era ni un retórico ni un sofista, ni un cínico, sino un hombre de fundamento y de corazón. Y además la sentencia forma parte de una oración de bendición, de alabanza y de acción de gracias a su Padre. Así, pues, aunque aparece como una oración en voz alta pronunciada por Jesús en presencia de sus discípulos, no está dirigida a ellos, sino a su Padre, y fue una efusión interior provocada por la alegría en el Espíritu Santo.

Es cierto que Jesús hablaba con paradojas, de tal manera que ese tipo de formulaciones en los Evangelios son un indicio de que estamos ante palabras auténticas de Jesús o por lo menos que contienen su sello característico. Pero, si es verdad que esos dichos no eran plausibles en la opinión establecida, sí tenían pleno sentido en el horizonte alternativo que Jesús se esforzaba por instaurar. Puede decirse que ponía sistemáticamente patas arriba a la lógica establecida porque estaba convencido de que ella había puesto patas arriba la realidad.

También puede parecer una paradoja e incluso una provocación que tome este dicho jesuánico como tema de una disertación académica. Puedo decir, con sencillez, que no ha sido esa mi intención. Era un tema que me venía esperando desde hacía bastantes años y que me parece adecuado para lo que ustedes han querido celebrar en este acto, ya que este dicho de Jesús expresa una de las fuentes más genuinas de la cristología latinoamericana y, más generalmente, de la teología y espiritualidad latinoamericanas, y ciertamente de mi quehacer teológico.

Espero mostrar que en el fondo es una invitación para colocar nuestras búsquedas intelectuales en un horizonte humanizador en el que den de sí todas sus potencialidades, corrijan sus malformaciones y sean realmente fecundas. 
Desarrollaré mi disertación en tres partes. En la primera, haré un breve estudio exegético y teológico de la sentencia. En la segunda, haré ver en un rápido recorrido que esta sentencia no es un dicho aislado, sino una formulación programática que explica la reacción polar a las actuaciones de Jesús y está corroborada por dichos que constituyen el núcleo de su Evangelio. En la tercera, propondré lo que a mi modo de ver significa hoy esta sentencia y cómo se viene realizando lo que en ella se propone. Finalizaré con una conclusión que contiene mi propuesta para ustedes, y antes que nada para mí mismo.

\section{Estudio de la sentencia}

\subsection{Análisis exegético}

\subsubsection{Precisión de términos}

El texto pertenece a la fuente común a Mateo y Lucas, una fuente de dichos de Jesús más antigua que el Evangelio de Marcos, que sería el que primero se redactó.

El primer verbo lo he traducido como bendecir ${ }^{1}$, pero podía haberlo traducido igualmente como alabar, aunque el primer sentido del verbo es confesar, y en este contexto significa que Jesús asiente a esa actuación de Dios, no solo la reconoce, sino que se adhiere a ella con alegría.

1. Traducen bendecir Schmid (Evangelio según san Mateo, Herder, Barcelona, 1967, p. 284), Trilling (El Evangelio según san Mateo, Herder, Barcelona, 19701, p. 255), Rius-Camps (El éxodo del hombre libre, El Almendro de Córdoba, Córdoba, 2000, p. 200), Mateos y Camacho (El Evangelio de Mateo. Lectura comentada, Cristiandad, 1981, p. 116), Luz (El Evangelio según Mateo, Sígueme, Salamanca, 2001, p. 267). Dice así Bonnard en su comentario a Mateo: "El verbo 'confesar-alabar-reconocer' (exomologein, en voz media con dativo) que Mt y Lc ponen en labios de Jesús. Viene del AT ( $c f$. las citas de Rom 14, 11; 15, 9; Flp 2, 11) y significa, particularmente en los salmos, reconocer y alabar a Dios por su obra de salvación (halal, cf. Sal 6, 6; 18, 50, etcétera)" (En Evangelio según san Mateo, Cristiandad, Madrid, 1976, p. 257). Fitzmyer, que traduce, como nosotros, "bendito seas", ofrece más citas y concluye que "esta fórmula de alabanza, aplicada a Dios, pertenecía a la mejor tradición del judaísmo palestiniense, de donde la tomó la primitiva comunidad cristiana" (En J. Fitzmyer, El Evangelio según Lucas, III, Cristiandad, Madrid, 1987, p. 256). Lo que no significa que el texto, en su sustancia, no se remonte a Jesús. Por el contrario, afirma que "es un ejemplo de su oración a Dios" (ibídem; cf. U. Luz, El Evangelio según Mateo, óp. cit., p. 271). También Dunn lo cree auténtico porque le parece "coherente con la intensa sensación de esperanza escatológica realizada, tan hondamente arraigada en la tradición de Jesús" (En J. Dunn, Jesús recordado, Editorial Verbo Divino, Estella, 2003, p. 803). 
Padre expresa la relación peculiar, más aún única, de Jesús con el Dios de Israel. Es el modo característico de referirse Jesús a Dios, tanto que es una entrada privilegiada a su persona ${ }^{2}$.

Señor de cielos y tierra, en el contexto, expresa la soberanía absoluta de Dios respecto de su creación y, en particular, respecto de la humanidad, más específicamente su soberanía sobre la historia humana ${ }^{3}$. Para Jesús, soberanía absoluta no equivale de ningún modo a un ejercicio caprichoso del poder, ya que el señorío de Dios es biófilo y su gloria consiste en que la creación llegue a su plenitud e incluso sea trascendida en su participación en la comunidad divina por medio de Jesucristo.

El que ese Señor de todo sea Padre no es revelación en el sentido textual de desvelamiento de algo que ya existía (en el sentido gnóstico, hoy casi dominante, de que Jesús se dio cuenta de modo eximio de algo común a todos los seres humanos), sino en el de un acontecimiento del que es portador el propio Jesús ${ }^{4}$. Claro está que es acontecimiento para la creación y la humanidad, y en cuanto él pertenece a ellas para el propio Jesús. Pero Jesús es el Hijo eterno humanado. Por hacerse humano, y no como individuo señero, sino como hermano universal, el Señor del universo es Padre de los seres humanos. Por eso es acontecimiento también para Dios.

Escondiste/revelaste. Esta contraposición es muy frecuente en la Biblia y expresa la plenitud del poder divino abarcando los dos extremos. "Tú das la muerte y la vida" (Dt 32, 39) o, como aparece en el Magnificat, glosando a Job, "derribó a los soberbios de sus tronos y ensalzó a los humildes, colmó de bienes a los hambrientos y a los ricos despidió vacíos" (Lc 1, 52-53; cf. Jb 5, 9-15), o,

2. El vocativo pater como invocación tampoco es frecuente: se arraiga en el uso personal del Jesús histórico (abba)" F. Bovon, El evangelio Según San Lucas II, Sígueme, Salamanca, p. 95; J. Fitzmyer, El Evangelio según Lucas, III, óp. cit., pp. 256-257).

3. "La tierra es el lugar que Dios ha creado para la humanidad; es el 'teatro de la historia' (...) Como Señor de cielo y tierra Dios es el creador y gobernador del universo". "Como Creador del universo y Señor de las naciones, Dios guía la historia de Israel, la de Jesús y la de la Iglesia" (J. D. Kingsbury, Conflicto en Lucas, El Almendro de Córdoba, Córdoba, 1992, pp. 17-18, 31). "Jesús deja trasparentar su experiencia de Dios, 'Padre', y prorrumpe en un canto de alabanza porque ya no hay dicotomía entre el plan de Dios ('cielo') y su realización concreta ('tierra')" (J. RiusCamps, El éxodo del hombre libre, óp. cit., p. 200).

4. Barreto explana con gran claridad la trascendencia social del acontecimiento de Jesús que, al unir Padre y Reino, reinterpreta todo el universo religioso y consiguientemente antropológico y social. Pero no hace ver que Jesús es Hijo único y, por tanto, que ese acontecimiento es también intratrinitario (En J. Barreto, "Reinado de Dios y revelación divina. Las señales del Reino", Revista Latinoamericana de Teología, 79 [2010], pp. 28-32; esto último lo desarrolla convincentemente en las pp. 37-39). 
como dice Jesús a Pedro, “todo lo que ates en la tierra quedará atado en el cielo y todo lo que desates en la tierra quedará desatado en el cielo" (Mt 16, 19).

La contraposición específica entre ocultamiento y revelación es típicamente apocalíptica. Ahora bien, aunque para los apocalípticos es Dios quien revela y no hay sabiduría humana capaz de sondear los secretos de Dios, es cierto que Dios revela a los que se ejercitan en la sabiduría (Dn 2, 21-22), como Daniel. Por eso, congruentemente, Nabucodonosor lo nombró jefe supremo de todos los sabios de Babilonia (Dn 2, 48) y le dio grandes riquezas y altísimos cargos. Sin embargo, Jesús alaba a su Padre porque los destinatarios de la revelación definitiva de la que él es portador no son los sabios, sino la gente sencilla ${ }^{5}$.

Para entender este tipo de textos tan provocativos, y en particular el que nos ocupa, hay que partir de que Dios, el Padre, no mete la mano en el mundo. Él actúa mediante dos personas que son como sus manos: actúa por su Palabra, por su Hijo, y por su Espíritu. Jesús nos atrae con el peso infinito de su humanidad y el Espíritu nos impulsa desde más adentro que lo íntimo nuestro. La atracción y la moción dan dirección y fuerza, posibilitan, pero actúan desde nuestra libertad, activándola, pero no menos que contando con ella.

En este sentido, es más propio decir que Dios revela, que decir que oculta. Es cierto que Dios da vida, es cierto que revela, que ensalza, que colma de bienes. No podemos decir, en el mismo sentido de causación directa (en el sentido que explicamos, por medio de sus dos "manos"), que mata, que oculta, que abate,

5. Bovon insiste fuertemente en este punto: "Jesús, y tras él los cristianos, que se sienten ciertamente los destinatarios de la revelación, saben que no forman parte de la élite intelectual de Israel. No desean ni se atreven a llamarse sabios. Al contrario, para cualificarse adoptan un término que Jesús había sacado de un depósito distinto del de la apocalíptica, el de los 'pequeños'. Inspirándose en la tradición profética, rompió con la autocelebración de los sabios, lo mismo que criticó la de los escribas. La polémica es manifiesta" (óp. cit., pp. 95-96). Para Luz "es innegable que Jesús se enfrenta a una amplia corriente de pensamiento apocalíptico, esenio y rabínico"; lo confirma con múltiples textos, pero luego asienta que "en textos sapienciales los matices son diferentes" y ve en ellos una aproximación real al texto que nos ocupa. Sin embargo, para él "la formulación antitética de la oración de Jesús apunta más allá del contexto judío. Y esto vale igualmente para la protesta profética contra la sabiduría engreída de los poderosos, a los que el Santo de Israel opone su 'no' (Is 5, 21; 29, 14-19; Jr 9, 22ss). Jesús, que contrapone la gente sencilla a los sabios de Israel y hace asequible a los primeros la revelación de Dios, se nutre por tanto de raíces bíblicas precisamente en su antítesis a la corriente dominante de la religiosidad judía" (U. Luz, El Evangelio según Mateo, óp. cit., pp. 279-280; J. Dunn, Jesús recordado, óp. cit.). Para Mateos y Barreto "los sabios y entendidos no captan el sentido de las obras de Jesús porque su insinceridad inutiliza su ciencia, impidiéndoles aceptar las conclusiones a las que su saber debería llevarlos. Los 'sencillos' no tienen ese obstáculo y pueden entender lo que Dios les revela” (óp. cit., p. 117). 
que despide vacío. Ahora bien, si las personas se resisten a esa acción salvadora, rehabilitadora, plenificadora, ellas se labran su ruina. El problema es que en la lengua de Jesús se dice con una misma forma gramatical la causación (propter hoc) y la consecuencia (post hoc).

Así pues, hay que decir que pertenece al misterio, es decir, al querer de Dios, a su modo de amar, el que tenga predilección por determinado grupo de personas; pero no podemos decir que odie o que mate o que actúe en contra de otras buscando su mal. En esos casos, habría que decir que la ceguera culpable de esas personas al amor de Dios es la que provoca su ruina ${ }^{6}$.

Sabios tiene en los Evangelios una connotación menos positiva en este caso, en que se equipara al uso que tiene en Pablo, que se refiere a la sabiduría de los que se tienen y son tenidos por sabios, a la sabiduría de este mundo, es decir, a una sabiduría meramente cultural, a inteligencia analítica e instrumental y erudición desconectada de la sabiduría de la vida. En este sentido, acusa que "jactándose de sabios se volvieron estúpidos" $(\mathrm{Rm} 1,22)$ y sostiene de un modo paralelo a nuestro texto que "como el mundo con su sabiduría no conoció a Dios en su divina sabiduría” (1 Cor 1, 21), quiso salvarlo por la necedad de la cruz. En el texto que comentamos, los sabios son de modo general las clases cultas y, más particularmente, los especialistas en la Torá, en cuanto se diferencian de los expertos, que son los que la llevan en el corazón: la experimentan ( $c f . \operatorname{Jr} 31,33$ ).

La gente sencilla (nephioi) son los pequeños, en cuanto ignorantes. Cuando no se refiere a los niños, es uno de los armónicos de la condición de pobres? Y los propios niños eran en esa cultura los que no contaban. Son los insignificantes. En el contexto de Lucas se refiere ante todo a los que han aceptado a los enviados, aunque también en el fondo a los mismos enviados. En el de Mateo se refiere más bien a los enviados, que, siendo insignificantes a los ojos del mundo, han creído en Jesús y, por tanto, han recibido la revelación del Reino. En ambos casos se resalta la condición de insignificantes. La pregunta sería si se trata de unos insignificantes especiales (aunque eso sería una contradicción) o de la revelación a los insignificantes. La respuesta es obviamente la segunda ${ }^{8}$.

6. "El hecho de que Dios 'oculta' ese saber no se debe a su designio, sino al obstáculo humano; se atribuye a Dios lo que es culpa del hombre. De hecho la realidad de Jesús está patente a todos, viene para ser conocido de todos" (Ibíd.; $c f$. W. Trilling, El Evangelio según san Mateo, óp. cit., p. 257).

7. Son los pobres de Yahvé de Sofonías. Ver J. Barreto, "Reinado de Dios y revelación divina", óp. cit., pp. 17-20.

8. “A mi juicio, los 'pequeños' se caracterizan en el Evangelio por una situación social poco favorable y una actitud espiritual hecha de disponibilidad, de humildad y de acogida sin pretensiones" (Bovon, óp. cit., p. 96, n. 22). Luz sostiene que en el v. 27, en el que se habla nuevamente de revelación, los sencillos "son ahora aquellos a los que el Hijo quiera revelar estas cosas, es decir, la comunidad. Se produce así en el 
Para entender el contenido de la sentencia, nos preguntamos ante todo qué son estas cosas que el Padre ha ocultado a unos y revelado a otros. En el contexto, estas cosas son lo que los discípulos anunciaron por encargo de Jesús, que es obviamente lo que Jesús mismo proclamaba con obras y con palabras, y más todavía con su presencia alentadora, es decir, el reino de Dios como reinado: el acontecimiento de que Dios venga a ejercer su soberanía sobre su pueblo y que esa soberanía sea saludable, tome la forma, no de juicio, como había imaginado el Bautista, sino de entrega incondicional de la salvación?

\subsubsection{Sentido de la sentencia en el contexto}

La perícopa que comentamos, en el contexto de Lucas que nos parece el original, forma parte de la reacción de Jesús ante lo que le han comunicado los discípulos sobre el resultado paradójico de la misión. Los discípulos esperaban que se interesara por su propuesta la gente más religiosa que frecuentaba la sinagoga y vivía pendiente de la ley. Y sin embargo, quienes les abrieron la puerta y los recibieron con alegría fue la gente sencilla, que no tenía mucha idea de las sutilezas de los entendidos.

Esto que se revela como paradoja a los discípulos en el desarrollo de su misión es, globalmente considerado, lo que pasó con la misión de Jesús en Galilea y Judea y también el resultado de la primera misión cristiana. Jesús da gracias a Dios y lo bendice porque no solo le parece que este resultado desen-

v. 27, junto con la concentración cristológica, una concentración eclesiológica de v. 25s. Esta implica un estrechamiento. Ahora no se habla ya de toda la gente sencilla de Israel, sino de la comunidad. Estos 'simples' poseen de nuevo su saber especial. Saben del misterio de Padre y del Hijo. Con el v. 27, la revelación a los nephioi se produce de nuevo en una mayor afinidad estructural con los textos apocalípticos y de Qumrán, que se referían igualmente a un grupo especial de personas y a su saber privilegiado" (óp. cit., p. 281).

9. "Las 'cosas' que Dios revela están relacionadas con el conocimiento de su plan de salvación; de que Dios, en su reinado escatológico, está presente en el ministerio de Jesús y de sus discípulos para derrotar a Satanás y salvar a los hombres (10, 17-20). En efecto, como dice Jesús a continuación, Dios se lo ha entregado 'todo' (es decir, todo conocimiento y autoridad) a él, que es su Hijo $(10,22)$. Por eso, él es el que revela 'quién es el Padre' (es decir, Jesús, en su persona y su ministerio, da a conocer a los hombres la presencia salvadora, la actuación, el designio y la voluntad de Dios)" (J. D. Kingsbury, Conflicto en Lucas, óp. cit., p. 188). "Se trata, pues, de comprender el sentido de las obras de Jesús, de ver en ellas la actividad del Mesías. La revelación del Mesías podía haberse hecho de manera deslumbradora y autoritaria. Sin embargo, el Padre ha querido hacerla depender de la disposición del hombre. Es la limpieza de corazón, la ausencia de todo interés torcido, la que permite discernir en las obras que realiza Jesús la mano de Dios" (J. Mateos y F. Camacho, El Evangelio de Mateo, óp. cit., p. 117). 
traña la realidad que ocultaba el orden establecido, sino que era, más radicalmente todavía, el beneplácito divino.

Así, pues, los sabios y entendidos eran ante todo los maestros de la ley, reconocidos como tales por el gremio, y funcionarios públicos, por estar en una teocracia. Pero también, los fariseos, que se esforzaban por cumplir hasta el último ápice de ella y que presionaban a los demás para que la cumplieran. Más en general, eran las fuerzas vivas, que participaban también en este punto del orden establecido, que era religioso, como fue posteriormente la cristiandad ${ }^{10}$.

Los sencillos eran la gente del común, que no tenía especial instrucción y tampoco tenían que ver con la marcha de los negocios y, más en general, de la sociedad ${ }^{11}$.

Un ejemplo bien significativo de lo que para los sanedritas era ese tipo de gente, que para ellos no tenía ni dignidad ni consistencia ni prestancia, son los Apóstoles Pedro y Juan, que comparecen ante ellos. Cuando les oyen dar testimonio de Jesús, se quedan estupefactos porque les hablaron con aplomo y sin fanatismo, razonando con congruencia lo que decían. El desconcierto vino porque quienes hablaban así eran "idiotas e iletrados" (Hch 4, 13), es decir, gente que no tenía arte ni parte en los negocios públicos y vivían atenidos a su vida privada, a su particularidad, y que, por no saber leer, no estaban ejercitados en el uso de la Sagrada Escritura.

Otro ejemplo característico es la reacción de los jefes de los sacerdotes y los fariseos al comprobar que la guardia del templo no ha traído preso a Jesús como les habían mandado. Los acusan no solo de no haber cumplido su orden, sino más todavía de no obrar como quienes por su oficio tenían que tener la mentalidad de los jefes del pueblo, que eran sus inmediatos superiores, ya que no lo trajeron porque se dejaron seducir por las palabras de Jesús. Les recuerdan que ninguno de los jefes ni de los fariseos se ha dejado embaucar por él. Solo el populacho ha visto en Jesús a un enviado de Dios. Pero la plebe no tiene ninguna autoridad porque, por desconocer la ley, son unos malditos (Jn 7, 45-49).

En ambos casos, los sencillos, el pueblo o, con otra palabra, los pobres, por serlo, no estaban al tanto, según los entendidos, de los designios de Dios, no tenían discernimiento y, por eso, ven en Jesús al enviado de Dios.

10. Luz matiza con precisión quiénes son sabios para los judíos, sostiene que no se restringe a los letrados y concluye afirmando que son "una clase social que se contrapone al "pueblo ordinario"” (U. Luz, El Evangelio según Mateo, óp. cit., p. 278).

11. "Jesús pensará en sus oyentes: las mujeres, los galileos, los pobres del campo que no tienen tiempo ni posibilidad de ir a la escuela de los 'sabios'. El am ha arts se puede identificar sobre todo con los nephioi” (Ibíd., pp. 278-279). 
También era evidente que Jesús no había estudiado ${ }^{12}$. Por eso, mucha gente se queda extrañada de que sepa tanto (Jn 7, 15), cuando los que sabían en su medio eran los que habían estudiado, como Pablo, por largos años con un maestro reconocido (Hch 22, 3). Jesús no había estudiado con maestros, se lo había revelado su Padre. No en el sentido estricto de una revelación, es decir, de que le dijera de un modo expreso cosas específicas, sino en el de que era su Padre porque se había entregado todo a él, constituyéndolo en Hijo suyo, y también en el sentido de que al ponerse Jesús en sus manos, como verdadero Hijo, y buscar siempre cumplir sus designios, hablaba siempre desde él, desde su perspectiva, desde su mentalidad, desde su sensibilidad, desde su voluntad.

Así, pues, es su propia vida, toda su vida ante Dios, la que capacita a Jesús para comprender lo que les había sucedido a sus discípulos en la misión a la que los había enviado.

Por eso Jesús se eleva en oración al Padre y lo bendice y alaba, porque lo que les ha pasado a sus discípulos no es una casualidad, una mera factualidad. Es nada menos que el cumplimiento del designio del Padre. No en el sentido de que se realiza fatalmente lo que él ha previsto, en el sentido literal del término, sino en el de que se realiza lo previsible: que quienes no tuvieron ningún interés en escuchar a los enviados de Jesús y por eso no les abrieron la puerta fueron precisamente los que creían que no tenían nada que pedir ni buscar porque en la Torá, que ellos pensaban que dominaban y cumplían, ya lo tenían todo; mientras que la gente sencilla, al tener conciencia de su situación de relativa exterioridad, de su condición de necesitados de salvación, al considerarse a sí mismos como gente en búsqueda, sí los recibieron con todo interés y se abrieron a su propuesta y les correspondieron ofreciéndoles su casa. Jesús se congratula al ver cumplido este designio del Padre.

Para los discípulos, en cambio, que participaban de la mentalidad de los entendidos, lo previsible era lo contrario de lo que pasó. Por eso se lo reportaron a Jesús con extrañeza. Esta expansión del corazón de Jesús, tan singular que en el Evangelio es la única oración de él que conocemos durante su ministerio, expresa, pues, algo medular en lo que él se sentía muy personalmente concernido.

El presupuesto de la mentalidad de los discípulos es que el orden establecido, aun con sus abusos, expresa la voluntad de Dios para su pueblo. Por eso, los representantes oficiales y los judíos practicantes son los que están más cerca de Dios y, por tanto, los más preparados para interesarse por su mensaje y para recibirlo. En cambio, la gente pobre, que son los pequeños, los ignorantes de las

12. "El mismo Hijo, que dice haberlo recibido todo del Padre (v. 22), es también uno de esos 'pequeños'. ¿Acaso no lleva el título de 'Hijo'? Sin la conciencia de ser 'hijo', con minúscula, no sería el 'Hijo', con mayúscula” (Bovon, óp. cit., p. 96). 
cosas de Dios, serían, según ellos, los menos interesados en lo que les iban a comunicar y los menos capacitados para comprenderlo y recibirlo.

Para Jesús, en cambio, la Torá no escrita no es expresión situada de la voluntad de Yahvé, sino tradiciones de sus mayores (Mc 7, 8), tradiciones meramente humanas sacralizadas que sustituyen a la búsqueda historizada de la voluntad del Dios de la alianza. Por eso Jesús no se refiere nunca a esas tradiciones, sino, lo más, al decálogo, en el sentido restringido de los mandamientos de la segunda tabla, y, aun así, expresa su insuficiencia para heredar la vida eterna (Mc 10, 17-21); cosa que no sucede cuando resume la ley en amar a Dios y al prójimo, reinterpretando radicalmente este segundo aspecto como aproximarse al necesitado para ayudarlo (Lc 10, 25-37). Esta diferente apreciación se debe a que se pueden cumplir los mandamientos, la mayoría de los cuales tiene una formulación negativa, por realismo, por prudencia, por sabiduría de la vida, para ser correcto. Todo esto está muy bien; pero su recompensa es vivir esta vida con la sabiduría y la felicidad que caben en ella. La vida eterna es la vida de las hijas e hijos de Dios, en Jesús, su Hijo único, y, por consiguiente, la vida de las hermanas y hermanos, en Jesús, el Hermano universal. Esa vida filial y fraterna está expresada en el mandamiento del amor a Dios y al prójimo, en el sentido que hemos expresado de aproximarse al necesitado, porque no tiene gracia amar solo al que es de los míos, o al rico que me va a corresponder (Lc 6, 32-34; 14, 12).

Hay que reconocer que, entonces y hoy, se puede cumplir lo pautado, lo establecido, y enseñarlo autoritativamente, sin ese amor específico en que consiste la vida eterna.

La propuesta de Jesús tiene otra lógica: él es el que se adelanta a amar concreta y gratuitamente, más aún, a entregarse completamente, y en su entrega fraterna Yahvé mismo es el que se está entregando como Padre materno. Como la entrega de ambos es incondicional, lo único que cuenta es la apertura a esa entrega, su aceptación y la consiguiente correspondencia.

Quien vive la alianza como un contrato por el cual quien cumple lo que Dios manda recibe de él la recompensa (de la riqueza, la salud y la descendencia numerosa y, si es caso, la otra vida), quien está ocupado en vivir desde esta perspectiva, no tiene interés por lo que acontece como novedad en la historia. Porque para él lo significativo, lo realmente trascendente, no acontece en la historia, sino que se juega en el cumplimiento de la ley. Este cumplimiento mira a las prescripciones concretas, no primordialmente a las relaciones personales. Hay leyes que pautan determinados comportamientos respecto de los demás. El intachable los cumple, pero no por las mismas personas, sino por respeto a Dios.

Para Jesús en esto consiste el extravío: la relación personal, ante todo con Yahvé y no menos con los demás, ha sido sustituida por el cumplimiento de unas prescripciones. 


\subsection{Sistematización teológica}

Reflexionemos sobre los datos que hemos presentado. Si el texto que nos ocupa es la única oración que los Evangelios nos han transmitido de Jesús en su vida pública (es decir, sin contar las de la pasión), es porque su contenido es no solo medular, sino altamente sintomático y significativo.

\subsubsection{Oración y misión}

Digamos, en primer lugar, que su oración se refiere a su misión, ya que a ella aluden "estas cosas" que el Padre ha revelado mediante el ministerio de Jesús. Su misión no es, pues, algo tangencial a su identidad más íntima, que es la que se supone se expresa en la oración: es su condición de Hijo único la que lo lleva a hacerse Hermano universal para hacernos a todos hijos en él, partícipes de su filiación. Ese es el designio de su Padre, al que asiente complacido. Jesús está, pues, con su Padre como nuestro Hermano mayor, como nuestro representante. Nosotros no venimos después, en un círculo en cierto modo externo a su intimidad con su Padre.

En esta oración se revela la insuficiencia de la división tradicional entre las obras de Dios ad extra, en las que él actúa como un todo, como un único actor, y las obras ad intra, en las que actúan las personas divinas como tales. O, más exactamente, se revela que la distinción real e insuprimible entre Dios y lo que no es Dios, no engendra una distancia insuperable. Jesús es el término medio entre Dios y su creación, y más concretamente el mediador entre Dios y la humanidad.

Hacerse ser humano no es, para el Hijo eterno de Dios, como piensa el hinduismo, un avatar, una figura provisional encaminada a una acción, que desaparece cuando esta se consuma. Hacerse ser humano es un acontecimiento intratrinitario permanente, algo que afecta a toda la Trinidad. Pero no menos es el acontecimiento decisivo de la creación y de la historia de la humanidad, ya que uno de la Trinidad es ya para siempre uno de la humanidad. Pero no solo uno de la humanidad, sino precisamente el Hermano de cada uno de los seres humanos y de la humanidad como tal.

En esta oración se revela el acontecimiento que proclama el cristianismo: que Dios se ha revelado comunicándose en su Hijo Jesús, dándose, entregándose hasta el punto de ser uno de nosotros, más aún, nuestro, porque nos lleva a todos en su corazón.

\subsubsection{Encarnación, concreción, limitación y preferencia}

Este es el designio, digamos, último, de Dios, del Padre materno. Pero lo paradójico, lo que para unos es escándalo porque les parece una discriminación intolerable, y para otros la buena noticia más formidable que puede escucharse, 
es que, de hecho, al acontecer, este designio, de suyo universal, se ha bifurcado: ha permanecido oculto para los sabios y se ha revelado a la gente sencilla.

Ya hemos insistido en que esta formulación, que es el contenido de la oración de Jesús, hay que entenderla como una causación directa de Dios en la revelación a los sencillos y como un resultado no querido por Dios, pero previsible para él, del efecto de la presencia reveladora de Jesús en los sabios.

Para comprender esta diversa postura de sabios y sencillos, hay que partir ante todo de una limitación insuperable en la encarnación del Hijo de Dios. La limitación que tenemos que aceptar de entrada es que no era posible que el Hijo único de Dios, al hacerse un ser humano, no se hiciera un ser humano concreto, situado de una manera específica en la trama social. Si el Hijo de Dios venía como hijo de Adán, como uno de los miembros de la historia humana, tenía que poseer especificaciones, y si poseía unas, carecía de otras. Tenía que nacer en un país concreto, luego no nacería en otros; en una clase social concreta, luego no en las demás. Si no podía entrar en el mundo de un modo genérico, de una manera indeterminada, como un mero universal lógico, no podía evitarse que la concreción aparezca como una preferencia. La preferencia no es definitoria: Jesús venía como ser humano concreto: eso era lo que lo definía. Pero también lo caracterizaban las especificaciones.

Pues bien, Papá Dios, como era inevitable que escogiera, escogió para su Hijo al pueblo de Israel, un pueblo insignificante, periférico y sometido al Imperio romano; y en él escogió a la provincia mestizada y semipagana por bastantes siglos (hasta la rejudaización forzosa que llevaron a cabo los macabeos) de Galilea (la Galilea de los gentiles, dice Mateo: 4, 15-16, citando a Isaías: 8, 23-9; 1), una región de la que los letrados decían que no salía ningún profeta (Jn 7, 52); y en Galilea escogió a un pueblo que no aparece en la Biblia hebrea, un pueblo, por tanto, insignificante, del que sus vecinos afirmaban que no podía salir nada bueno (Jn 1,46); y en el pueblo escogió a una familia de la que sus vecinos no esperaban nada especial (Mc 6, 2-3); y en su familia, a una persona que, según sus familiares, no daba sino para lo que era (Mc 6, 3; 3, 21; Jn 7, 2-5). Una familia que, al presentar en el templo a Jesús, su hijo primogénito, no pudo ofrecer sino la ofrenda de los pobres $(\operatorname{Lc} 2,24)$.

Esta elección divina es desconcertante hasta para los mismos pobres, muchos de los cuales, por no tener cómo tener, viven en algún tipo de dependencia o, al menos, de minusvalía.

Esta elección ¿no lo incapacitaba para una misión tan compleja y cualitativa? Para una misión tan decisiva ¿no había que haber elegido lo más cualificado que había en ese momento histórico? 


\subsubsection{Preferencia y misterio; sentido de la preferencia}

La primera respuesta a esta objeción es que Dios hace lo que quiere y que nosotros no somos sus consejeros, y que esa sería una pretensión, más que blasfema, ridícula. Dios hace lo que quiere y sabe lo que hace. Dios todo lo hace bien. Y esta decisión tan trascendente no solo para nosotros, sino, sobre todo, para él, ¿no sería la más correcta?

Si creemos en él, es decir, si confiamos en él y nos ponemos en sus manos, ¿no tendríamos no solo que acatar su decisión, sino que asumirla como la mejor? ¿No tendríamos, entonces, que tratar de pensar por qué es la más adecuada para su misión?

Lo que a mí se me ocurre al respecto es que, si Jesús hubiera nacido en una familia moralmente sana, rica, letrada y bien posicionada y él se hubiera levantado con todos esos atributos, de entrada, sería inevitablemente superficial, en el mejor sentido de esta palabra. Lo sería porque con esa inalcanzable ventaja inicial no necesitaría profundizar en sí asumiendo todas sus potencialidades e incluso yendo más allá de ellas: con lo puesto, tendría suficiente y de sobra. Una persona así ipuede comprender a los que ponen todo de su parte y no alcanzan lo indispensable porque están en una enorme desventaja y las reglas de juego les son adversas? Una persona así ¿puede hacer de puente entre la mayoría de la humanidad y su Creador, y entre unos seres humanos y otros?

Una persona que nace y vive donde se crio Jesús tiene muchas probabilidades de vivir restringida al mínimo vital, si es suficientemente lúcida como para percibir la brecha casi infranqueable que la separa de los que son algo, y, por tanto, la probable futilidad de su esfuerzo; o puede convertirse en un arribista que da la espalda a los suyos e ingresa al mundo de los triunfadores, dispuesto a ascender, si percibe en sí cualidades y comprende la lógica social y la aprovecha para su medro; o puede apostar por el desquite revolucionario o, en todo caso, por la violencia vengativa, si siente en la sangre la injusticia que pesa sobre él y los suyos. Pero, si vence esas tentaciones, una persona de ese medio, con esas cualidades, es sin duda la más apropiada para lograr la fraternidad de las hijas e hijos de Dios, a la que se opone frontalmente la injusticia, el desprecio y más aún la indiferencia de los de arriba y la postración fatalista de los de abajo.

Creo que, visto humanamente, es razonable, aunque muy arriesgada, la opción de Papá Dios. Más todavía, creo que es la única opción: solo desde abajo puede lograrse el bien de todos: solo cuando a los pobres les vaya bien, les irá bien a todos. Hoy más que nunca somos conscientes de que el bien de los de abajo no se logra por el rebosamiento hacia ellos del crecimiento y la abundancia de los de arriba. Aunque no es fácil que lo vean así y que lo acepten con gusto, o al menos con realismo, los de arriba, que son los enterados, los generalmente 
bien informados, los que tienen suficientes elementos para decidir con tino, los que Jesús llama en su oración los sabios y entendidos.

\subsubsection{Marginación y misión}

Pero, además, esta elección de Papá Dios respecto de su Hijo Jesús es refrendada y radicalizada por él, cuando es llamado a la misión. El Evangelio relata que alguien se ofrece con toda generosidad a seguirlo adonde quiera que vaya, y Jesús le responde: "Yo no tengo dónde reclinar la cabeza" (Lc 9, 58); es decir, no tengo adónde ir; si me sigues, me sigues para vivir en el camino. Esta respuesta tiene que ser entendida en su sentido más literal. Jesús dejó su pueblo, su profesión y su familia. Dejó, pues, su identidad, su lugar en el mundo, su seguridad vital, aunque precaria, y su derecho a ser considerado, que eso es lo que significa la expresión "pobre, pero honrado": con derecho a que se le respete, antes que con congruencia vital. Jesús tenía derecho al respeto porque tenía un lugar en el mundo: un pueblo, una casa y familia, un oficio. Al dejarlos, se convierte en $o_{j l o s}{ }^{13}$, en lumpen, en chusma, en esa masa que vive en la calle o en algún refugio precario y que no tiene nada que hacer ni adónde ir.

Claro que no es igual que ellos. Él ha elegido ese modo de vida y sí sabe por qué y para qué, sí tiene una misión que totaliza su vida. Pero, como ellos, no tiene ningún medio de vida ni pertenencia reconocida. La calle y el campo (en su caso, el lago) son su hábitat. Se mueve donde se mueven los que no tienen recintos privados, lugares exclusivos.

Pero no elige solo las condiciones materiales de vida. También, o congruentemente con ellas, elige comenzar la misión no por la capital ni por las ciudades helenizadas de Galilea, Séforis y Tiberíades, que nunca aparecen en los Evangelios como escenario de su vida ni de su misión, sino por los caseríos y pueblos, para acabar finalmente, y escoltado por miles de peregrinos galileos, en la capital.

Como en el caso de su ubicación en la historia, nos tenemos que preguntar por la razón de ese modo de realizar su misión, que, recordemos, es el contenido de la oración que nos ocupa. ¿Por qué quiso Jesús quedarse sin nada como el modo más adecuado de realizar su misión? Como en el caso anterior, tendríamos que responder que así le pareció bien. Y, si somos cristianos, tenemos no solo que

13. Castillo, además de explicar el significado de ojlos y cómo en el Evangelio es el nombre dado de preferencia a la multitud que sigue a Jesús y con la que él convive, desarrolla el tema que nos ocupa de que su mensaje era sobre todo para ellos y que ellos fueron ante todo los que vieron en su mensaje, en su acción y, radicalmente, en su presencia una buena nueva para ellos, y por eso lo siguieron (En J. M. Castillo, "Jesús, el pueblo y la teología. I", Revista Latinoamericana de Teología, 44 [1998], pp. 111-131). 
aceptar esa decisión, sino que asentir a ella con el entendimiento, valorándola como la más adecuada.

La razón que se me ofrece de esta adecuación es que de este modo instauraba la reciprocidad de dones, como la alternativa divina de la que era portador, respecto del intercambio de bienes y servicios en el que cada quien busca su propio provecho, que es el modo de relación dominante en la historia. Esta alternativa implica el juicio negativo de que en el esquema vigente no puede lograrse la fraternidad de las hijas e hijos de Dios, que es lo que el Hijo viene a traer a la tierra como designio definitivo del Padre.

Jesús viene a dar su sabiduría, su compañía alentadora, sus hechos liberadores y rehabilitadores; más aún, no solo da de sí, sino que se da completamente a sí mismo como nuestro hermano. La persona o la casa, la familia, que recibe este don de Jesús se siente tan confortada y agradecida por él que le ofrece a su vez su casa en señal de fraternidad. De este modo, en el esquema que propone Jesús, no hay nadie que solo dé ni nadie que solo reciba: todos dan y todos reciben. Es la reciprocidad de dones como modo de creación de humanidad ${ }^{14}$.

Jesús es muy sensible respecto de esta fraternidad: la acepta y la agradece, ya que un hermano no se contenta con serlo él personalmente, sino que quiere que los demás también vivan como tales.

\subsubsection{La oración de Jesús refleja ante todo su vida}

Así, pues, el contenido de esta oración de Jesús valía ante todo para sí mismo. Él fue tenido por los dirigentes e incluso por sus paisanos como uno del común, como uno que no ha estudiado, como gente sencilla, como insignificante, como no apto para ninguna misión trascendente; y sin embargo, es a él a quien Papá Dios reveló los misterios del reino, y más todavía, todo lo puso en sus manos y él mismo se puso en sus manos. Dios nos hizo hijos verdaderos suyos a través de la fraternidad de este individuo tenido como insignificante. Y no obstante, fue él precisamente, él, que tenía que recibir diariamente comida y alojamiento para poder vivir, quien, como dice lúcidamente Pablo, "nos enriqueció con su pobreza" (2 Cor 8, 9).

Jesús no pudo dar, como Zaqueo, la mitad de sus bienes a los pobres; ni pudo, como el samaritano, verter aceite y vino sobre las heridas del que había caído en manos de los ladrones, ni montarlo en su cabalgadura, ni llevarlo a una posada y pagar al posadero por los servicios que le hiciera. Jesús, como no tenía cosas para dar, dio de sí y se dio a sí mismo; pero dio tanto que eternamente seguiremos viviendo de su don.

14. Castillo, en el artículo mencionado, subraya esta mutua solidaridad entre Jesús y el ojlos (ibíd., pp. 131-136). 
¿No es un escándalo para la lógica establecida que aquel a quien más deba la humanidad sea una persona sencilla, una persona del común, una persona sin los atributos de saber letrado y de poder económico y político que hacen que un individuo sea alguien? Jesús, como acogió desde el comienzo la entrega que Papá Dios le hacía de sí, sin dejar de ser en su porte y en su hábitat uno de tantos, gente sencilla, llegó a ser no solo paradigma de humanidad, es decir, un ejemplar humano tan humano que en él reluce de modo absolutamente sobresaliente lo que es ser humano, sino también, lo que es decisivo, arquetipo de humanidad porque la relación con él humaniza. Jesús sabe lo que dice en su oración porque él es una persona sencilla dignificada por la revelación de Yahvé, su Padre materno ${ }^{15}$.

\subsubsection{Cómo se fue dando la revelación del reinado de Dios a la gente sencilla}

Lo que ve realizado en él, lo ve realizado también en esa gente sencilla que para los entendidos era una masa despreciable. Ve que se va realizando como fruto de su misión y la de sus discípulos, que pertenecen también a ese colectivo de gente sencilla.

¿En qué consiste esa realización y cómo la va llevando a cabo? Consiste en que se encontró con una masa desperdigada porque estaba maltrecha y desalentada, como ovejas sin pastor (Mt 9, 36), y con su presencia y con su acción la fue convirtiendo en un pueblo en pie y movilizado. La gente sencilla no eran ciudadanos con derechos reconocidos. Sus dirigentes no eran representantes suyos ni buscaban su elevación, sino que se descargaban en ellos y los abrumaban con los tributos, además de despreciarlos. Por eso estaban no solo maltrechos por la carga excesiva, sino abatidos, contra el suelo, sin ninguna esperanza. Jesús, el buen pastor, el dirigente modelo, conocía a los suyos, los conocía no solo por simpatía, sino porque durante treinta años perteneció a ese pueblo, porque era uno de ellos. Los conocía no para aprovecharse de ellos, sino para reconocerlos, y para que se reconocieran a sí mismos y unos a otros.

¿Cómo lo logró? Ante todo, estando con ellos, de tal modo que percibieran que era de ellos, que tenían derecho sobre él, sobre su tiempo, sobre su atención, incluso sobre su persona. La mayoría de las escenas evangélicas suceden en el

15. "Por eso el gran signo del Reino es un hombre, y un hombre en su condición límite de su solidaridad con el hombre. En ese límite es donde se trasparenta sin equívocos la presencia de Dios que trasforma al hombre elevándolo por encima de la condición humana; un signo que los letrados y fariseos no pudieron entender (Mt 12, 38ss) (...) Por eso la gran señal terminará siendo para los discípulos Jesús mismo, y no principalmente en calidad de maestro, sino en su condición de expresión, él mismo, del amor de Dios que queda patente en su modo de actuar con el hombre necesitado, y sobre todo en su modo de morir como expresión extrema de su amor. Solo así se entiende cómo en una muerte así el hombre eclosiona como la expresión más cabal de la realidad divina" (J. Barreto, "Reinado de Dios y revelación divina”, óp. cit., p. 34). 
camino o en lugares deshabitados, en ejidos, a orillas del lago, donde está la gente menuda. Todos acceden a él, no le dejan espacio ni tiempo para comer; cuando van caminando no mantienen ninguna distancia, sino que quieren estar con él y le estrujan por todos lados. Le plantean todo lo que se les ocurre sin ningún protocolo. Y ¿por qué quieren estar con él? ¿A qué se debe tanta asiduidad? ¿Por qué esa cercanía tan absoluta engendra tanto respeto? Porque Jesús liberaba sus mentes con su palabra. Lo característico de él son las parábolas y las sentencias. Ambas tratan de los asuntos más cotidianos, pero lo hacen fuera de la lógica establecida: paradójicamente. Con eso les da que pensar. Él está convencido de que la realidad está patas arriba y por eso la pone al revés para devolverla a su sitio.

Vamos a poner cuatro ejemplos. En esa sociedad integrada, aunque desigualmente, todos estaban catalogados: había árboles malos y buenos. La higuera no puede dar sino higos y de la zarza no se recogen uvas. Cada quien es lo que es y ya se sabe qué se puede esperar de cada uno. Por ejemplo, de la gente sencilla, que no conoce la ley, no se debe esperar nada. Y sin embargo, Jesús afirma que el árbol se conoce por sus frutos (Mt 7, 15-20). No se fía de las clasificaciones apriorísticas. Como se ve, para Jesús, la naturaleza fija es típica de las plantas, pero no de los seres humanos, que estamos abiertos y nos definimos por nuestras obras. Naturalmente que esto suena a desconfianza inadmisible para los bien considerados, que son los entendidos en la ley, pero suena a un reto esperanzador para aquellos de los que no se esperaba nada, que son la gente sencilla.

Por eso, él esparce la semilla de su palabra sobre toda clase de tierras, porque el corazón que es duro como la tierra del camino puede llegar a abrirse; y el corazón mezquino, como la tierra entre piedras, puede llegar a ser generoso; y el corazón dividido, como la tierra entre zarzas, puede unificarse en torno a lo genuino: todos podemos llegar a ser tierra buena (Mc 4, 3-9).

Un señor invita a un banquete, pero los invitados, acostumbrados a comer muy bien diariamente, no se sienten motivados por la invitación y se excusan: son gente importante y están en lo suyo. Por eso quienes acaban comiendo el banquete son los que andan por las calles y plazas, y los pobres y lisiados (Lc 14, 15-24). La invitación de Dios, de la que es portador Jesús, no interesa a quienes creen estar al tanto de su voluntad, porque son los entendidos, los que están en la normalidad religiosa, es decir, ellos ya cumplen con Dios y no les interesan esas novedades. En cambio, quienes por ser tan pequeños no se creen con ningún derecho, se sienten tremendamente estimulados por esa invitación y acuden a ella.

Para adquirir el tesoro, que es la relación filial con Dios al aceptar la fraternidad de Jesús, hay que venderlo todo: para definirse como hijo de Dios hay que dejar de definirse por riquezas, por poder o por sabiduría. Los que descansan en ellas no creen que sea buen negocio y prefieren seguir como antes. Pero quienes no tienen nada, claro que están dispuestos a dejar lo poco que tienen para 
adquirir lo que sí captan como un tesoro infinitamente mayor que ellos y lo suyo (Mt 13, 44).

El resultado es que los sencillos reciben a Jesús y a su Padre materno y los entendidos se cierran a su propuesta. Era previsible. Mientras los entendidos no capten que no saben nada de lo esencial, de lo que conduce a la vida verdadera y a la humanización integral, y se pongan, como los sencillos, a escucharle, no tienen remedio. Su sabiduría, en vez de un camino abierto, se convierte en una muralla que los enclaustra en sí mismos. Es lo que aparece en la oración que comentamos ${ }^{16}$.

\section{Sentido de la sentencia en el conjunto de los Evangelios}

El tema es decisivo porque es distinto que la sentencia, aunque desvele algo esencial, sea un dicho aislado, que no tiene paralelos en los Evangelios, sea una pieza, sobresaliente es verdad, pero de una estructura que abarca todos los niveles de la vida de Jesús, tal como la atestiguan los Evangelios. Como vamos a mostrar, se trata de esto segundo. Lo vamos a desarrollar desde dos acercamientos: ante todo, en las obras de Jesús y, luego, en las palabras que les dan su sentido exacto colocándolas en el horizonte adecuado de interpretación.

\subsection{Sentido de la sentencia en la práctica de Jesús}

Lo primero que queremos anotar es el efecto diverso de las acciones de Jesús en ambos colectivos, tal como aparece repetidamente, más aún de modo sistemático, en los Evangelios ${ }^{17}$. Llamamos teofanía a la manifestación de Dios, a la

16. Refiriéndose a la sentencia que comentamos y enmarcándola en el contexto de su vida, comenta Barreto: "El centro de la secuencia lo constituye, pues, la declaración de la relación mutua de conocimiento del Padre y el Hijo que se manifiesta solo a los sencillos. Por el contexto de toda la sección queda claro que las obras de Jesús, sus intervenciones a favor de los necesitados, son intervenciones de Dios en cuanto Padre y que, por lo mismo, ponen de manifiesto su condición de Hijo. Solo podrán conocer al uno y al otro aquellos que, abiertos a la misericordia como al rostro de Dios, entiendan que este se hace visible necesariamente en la intervención en las situaciones humanas degradadas. Los arrogantes y despiadados, por su propia condición, se quedarán al oscuro de esta revelación" (J. Barreto, "Reinado de Dios y revelación divina", óp. cit., p. 29).

17. Víctor Codina resume así este punto: "Aplicando todo cuanto hemos visto antes a la fe del pueblo (LG 12), la de los pobres y sencillos, podemos afirmar que el Espíritu les confiere a ellos una especial connaturalidad con el Reino de Dios, les abre los ojos del corazón para que puedan comprender lo que los sabios, que se fían de su propia sabiduría, no logran captar. Esto explica por qué el pueblo sencillo de Galilea sintonizó con Jesús, mientras que los escribas y fariseos y los sacerdotes lo rechazaron. Los pobres comprenden con facilidad que el Reino es un proyecto de vida y de justicia que se opone a la idolatría del dinero, de Mamón, que es la causa de 
percepción de la presencia de Dios o de lo divino en nuestra tierra y en nuestra historia, o, más exactamente, por lo que toca a la Biblia y más restringidamente a los Evangelios, la manifestación de Dios en un acontecimiento, a través de un mediador, de un enviado suyo. En los Evangelios, aunque aparecen los ángeles como enviados de Dios (solo en los Evangelios de la infancia y en las apariciones del Resucitado ${ }^{18}$ ) y se presenta a Juan Bautista también como enviado suyo $^{19}$, el enviado por excelencia es Jesús.

Los efectos que causan las teofanías, tanto en la historia de las religiones como en la Biblia y específicamente en los Evangelios, son dos: la admiración y el temor. Ambos son complementarios, aunque normalmente se destaque uno de ellos ${ }^{20}$. La admiración por la alegría ante esa densidad de ser, percibida como benévola, que se hace presente, ante ese hecho de salvación en el que se advierte la presencia bienhechora del Dios que salva. La admiración incluye la salida de sí y la atracción al campo de lo divino. El temor o, más exactamente, el sobrecogimiento, es el repliegue sobre sí mismo ante la presencia de ese sobreexceso de ser que pone al descubierto no solo la pequeñez propia, sino la indignidad, que lleva a retraerse de esa presencia, que aunque sea bienhechora, es demasiado para uno. Un caso que ilustra a la perfección lo que decimos es la reacción de Pedro ante esa pesca tan excesiva lograda por obedecer a la palabra de Jesús después de una noche estéril. Le dice que se aparte de él porque es un pecador ( $\operatorname{Lc~} 5,9)$. No puede evitar decirle eso cuando lo que quiere es, sin embargo, permanecer para siempre con él, y, si Jesús le hiciera caso, sabe que su vida se hundiría en el vacío. Se siente atraído por el peso de vida que Jesús aporta a la suya, pero siente que esa gracia es tan excesiva que le dice que se aparte. Es el ser divino o, más exactamente, el enviado de Dios, el que suelda esta distancia diciendo la frase proverbial: no temas (Lc 5, 10).

los males y de la pobreza del mundo (Mt 6,24)" (V. Codina, "La fe de los insignificantes", Revista Latinoamericana de Teología, 76 [2009], pp. 93-94).

18. Lc 1, 1.26; 2, 9.13; Mt 1, 20; 2, 13.19; Mc 16, 5; Mt 28, 2.5; Jn 20, 12 . Además, en Marcos 1, 13, en la representación de las tentaciones se dice que los ángeles lo servían, y en Lucas 22,43 , en un pasaje de la oración del huerto que falta en no pocos manuscritos, se afirma que un ángel del cielo lo confortaba.

19. Mc 1, 2-8; 11, 30; Lc 7, 26-28; Jn 1, 6-8; 3, 33-35.

20. Sobre la teofanía y sus manifestaciones en la historia de las religiones desde la perspectiva cristiana, véase R. Otto, Lo santo. Lo racional y lo irracional en la idea de Dios, Alianza, Madrid, 2001; y la recopilación complementaria Ensayos sobre lo numinoso, Trotta, Madrid, 2009, pp. 17-68, 151-164; también J. Martín Velasco, Introducción a la fenomenología de la religión, Trotta, Madrid, 2006, pp. 96-98. Para el horizonte en que se inscribe el mysterium tremendum et fascinans, ver óp. cit., pp. 558-568. 


\subsubsection{La gente sencilla se admira y se sobrecoge ante las acciones de Jesús}

Pues bien, en los Evangelios quienes se admiran y sobrecogen como reacción a la revelación de Dios en Jesús son, sobre todo, la gente sencilla. Así se dice como colofón de los milagros. Después de curar al paralítico, a quien traen sus amigos, "todos los presentes se quedaron admirados y alababan a Dios diciendo: "nunca habíamos visto cosa semejante" (Mc 2, 12). Según Mateo, se quedan sobrecogidos y alabaron a Dios "porque había dado tal autoridad a los humanos" $(9,8)$. Se refieren a la autoridad tanto de perdonar los pecados como de liberar de la parálisis. Esto lo percibe solo la gente, pues los fariseos, los entendidos, se pusieron más bien a murmurar de él. Como se ve, entre los dos evangelistas se enumeran los dos armónicos (unos sienten más uno y otros el otro) y aparece clara la contraposición entre ambos grupos sociales.

Cuando expulsó un demonio de un hombre mudo y este empezó a hablar, "los presentes decían admirados: 'NNunca se ha visto en Israel nada parecido!'. En cambio, los fariseos decían: 'El propio jefe de los demonios es quien le da este el poder para expulsarlos"' (Mt 9, 33-34). La gente se admira ante lo que percibe como intervención con el poder de Dios y, sin embargo, los entendidos no se abren a esta manifestación de Dios, y, por el contrario, la malinterpretan y descalifican al enviado. Mateo vuelve a contar un caso parecido, esta vez un ciego y mudo: "Jesús lo sanó, de manera que el mudo comenzó a hablar y a ver. Y todos los que presenciaron esto decían admirados: ‘'Será este el Hijo de David?'. Pero los fariseos, al oírlo, replicaron: 'Si este expulsa los demonios, es porque Belcebú, el propio jefe de los demonios, le da el poder para expulsarlos"” (12, 23-24). Así como los entendidos no se abren al carácter salvífico del acontecimiento y satanizan a su autor, la gente sencilla es capaz de interpretarlo como signo mesiánico, es decir, propio de los tiempos en que vendría la salvación definitiva, que es lo mismo que ocurre con Jesús cuando los enviados del Bautista le preguntan si es él el que ha de venir: el enviado definitivo de Dios. Jesús les remite a sus curaciones y a la evangelización de los pobres como las señales fehacientes de la llegada de la salvación definitiva (Lc 7, 18-23; $c f$. Is 26, 19; 29, $18 ; 35,5-6 ; 61,1)$.

Después de resucitar al hijo de la viuda de Naín, "todos los presentes se llenaron de temor y daban gloria a Dios diciendo: "Un gran profeta ha salido de entre nosotros y Dios ha bendecido a su pueblo"' ( $\operatorname{Lc} 7,16)$. Para la gente, en Jesús, Dios estaba pasando por el pueblo bendiciéndolo. Como este paso salvador no se detiene ni ante la muerte, ante la que nada podían los dioses de los pueblos circunvecinos, la gente se sobrecoge por ese peso de vida tan excesivo.

Después de curar a un sordomudo, la gente, llena de admiración, sintetiza todo lo que ha percibido de Jesús diciendo: "Todo lo hizo bien: hace que los sordos oigan y que hablen los mudos" (Mc 7, 37). La gente repite las mismas 
palabras que pone el Génesis en boca de Yahvé, después de concluir su creación: "Y vio Dios todo lo que había hecho y todo era muy bueno" $(1,31)$. Así, pues, la paradoja es que la gente sencilla, los que no saben, los insignificantes, son los que perciben el paso de Dios en Jesús por su tierra renovando la creación menoscabada. Lo perciben porque tienen ojos para ver. Y esa apertura, además de ser la disposición más personal de la gente, es, más profundamente aún, el don de Dios que les revela a su Hijo.

Como preámbulo a la segunda multiplicación de los panes, Mateo presenta a Jesús en la montaña rodeado de una multitud doliente traída por sus seres queridos: "Se le acercó mucha gente trayendo consigo cojos, ciegos, tullidos, mudos y otros muchos enfermos. Los pusieron a los pies de Jesús y él los curó a todos. La gente estaba admirada al ver que los mudos hablaban, los tullidos recobraban la salud, los cojos andaban y los ciegos veían. Y todos alabaron al Dios de Israel" (15, 30-31). La gente no se queda en el beneficio: se admira de la presencia del Dios misericordioso que en Jesús se acercaba a ellos salvándolos y por eso alabaron al Dios de la alianza.

La curación de un niño epiléptico está narrada con inusitado dramatismo. Más aún, en ella aparece la frase más dura de Jesús respecto de sus contemporáneos, como reacción ante la superficialidad del padre del niño, que lo trata como un mago y no asume su problema. Dice: "¡Gente incrédula y pervertida! ¿Hasta cuándo tendré que estar con ustedes? ¿Hasta cuándo tendré que soportarlos?". Pero después de ese desahogo, se hace cargo del problema y ayuda a que su padre se implique en él, y luego cura al muchacho y se lo entrega a su padre. "Todos se quedaron atónitos al comprobar la grandeza de Dios" (Lc 9, 41.43). En esa expresión se funden el sobrecogimiento y la admiración. La gente se ha abierto al sentido de ese acto y en él ha comprobado la grandeza de Dios, que está sobre la normalidad de las posibilidades humanas y a su favor.

La entrada triunfal en Jerusalén culmina en el templo. Allí, según Mateo, "se acercaron a Jesús algunos ciegos y tullidos y él los curó. Pero los jefes de los sacerdotes y los maestros de la ley se sintieron muy molestos al ver los milagros que Jesús había hecho y al oír que los niños gritaban en el templo dando vivas al Hijo de David" (21, 14-15). Al entrar al templo el enviado definitivo de Dios, los representantes oficiales de él, los que poseen la sabiduría y el poder sagrados, lo desconocen; y sin embargo, estos pobres necesitados acuden a él porque lo reconocen como el portador del poder de la misericordia divina, y son curados. Y unos niños, los más insignificantes, son los que lo aclaman como el Mesías, ante la indignación de los poderosos y entendidos. 


\subsubsection{La gente se admira ante las enseñanzas de Jesús}

La gente sencilla no solo se admira y sobrecoge por los signos de Jesús que rehabilitan la vida de sus seres queridos; se admira ante todo por su enseñanza. Así lo constata Marcos en la primera aparición de Jesús en público, un sábado en la sinagoga: "Todos quedaban admirados por sus enseñanzas, porque los enseñaba como quien tiene autoridad y no como los maestros de la ley (...) Todos se quedaron admirados hasta el punto de preguntarse unos a otros: '¿Qué está pasando aquí? Es una nueva enseñanza, llena de autoridad. Además, este hombre da órdenes a los espíritus impuros y le obedecen"' $(1,27)$. La primera novedad es meramente formal. En este sentido, autoridad se contrapone a autoridades. Como los rabinos no se sienten con autoridad, se apoyan en otros maestros más autorizados. Jesús, por el contrario, no se apoya ni siquiera en la Escritura (solo la cita en disputas con los sabios). Él afirma directamente lo que es la realidad y el designio de Dios sobre ella.

Esta novedad tan inaudita equivalía a ponerse directamente en el lugar de Dios como su oráculo. ¿Por qué la gente no lo apedrea como blasfemo? Porque ve, en efecto, que lo que dice desvela completamente la realidad y llega hasta el fondo de su corazón, porque palpa que su pretensión no es ilusoria, sino creíble, fehaciente. La gente capta en las palabras de Jesús la misma autoridad de Dios.

Así lo afirma también Mateo como colofón del Sermón del Monte, en el que Jesús, como nuevo Moisés, ha dado la nueva ley al nuevo pueblo de Dios. ¿Quién es este pueblo? Los necesitados, a los que pertenecen los discípulos (Mt 4, 23-5, 1). Pues bien, de estos insignificantes se dice que cuando Jesús terminó su discurso "estaban profundamente impresionados por sus enseñanzas, porque los enseñaba con verdadera autoridad y no como sus maestros de la ley" (7, 28-29). Nuevamente, la paradoja de que los sencillos tuvieran esa capacidad de discernimiento.

Así lo vuelve a recalcar Mateo cuando Jesús iba a culminar su ministerio y discutía con los maestros de la ley que buscaban desprestigiarlo delante de la gente: "Escuchando a Jesús, la gente se quedaba admirada de su enseñanza" $(22,33)$. Marcos, por su parte, recalca que, como reacción ante estas disputas de Jesús con los maestros de la ley en su última semana en Jerusalén, "la gente que lo escuchaba, que era mucha, disfrutaba al oírlo" $(12,37)$. No solo capta su autoridad, en contraposición a los especialistas, sino que capta que esa autoridad es en orden a su salvación, está a favor de ellos, los dignifica. Y por eso se contenta al escucharlo.

Ya dijimos que la máxima contraposición entre la capacidad que tienen los sencillos de captar en Jesús la revelación de Dios y la incapacidad de abrirse de los entendidos, que son las autoridades, los que tienen el poder ideológico y policial, se da cuando los jefes mandan a los guardias del templo a que prendan 
a Jesús y estos regresan con las manos vacías. Al dar razón de por qué no lo han traído, dicen la frase más contundente de todo el Evangelio: "Jamás nadie habló como este hombre" (Jn 7, 46). Los jefes les recriminan porque, al hablar así, hablan como esa chusma que ha creído en Jesús porque no conoce la ley y por eso son unos malditos. Por eso, por su condición de instruidos, no ha creído en él ningún jefe $(7,47-49)$.

No es que los entendidos no se sientan admirados ante la prestancia de Jesús, sino que se niegan a reconocerla. Por ejemplo, cuando quieren cazar a Jesús con la pregunta sobre el tributo al César, se admiran realmente de la perspicacia de Jesús (Mc 12, 17), pero, en vez de rendirse ante ella, se callan rencorosamente: "Y no consiguieron cazar a Jesús en palabra alguna inconveniente delante del pueblo. Al contrario, estupefactos ante la respuesta de Jesús, tuvieron que callarse" (Lc 20, 26).

El cuarto Evangelio comenta incluso que los jefes se admiran de la sabiduría de Jesús, pero como, a diferencia de la gente sencilla, no quieren concluir que es Dios quien se la ha dado, no pueden salir de su perplejidad: "Los judíos, admirados, se preguntaban: ‘Cómo es posible que este hombre sepa tanto sin haber estudiado?"' (Jn 7, 15). Jesús les responde que su doctrina no es suya, sino de su Padre que le ha enviado. Pero como ellos no quieren sacar esa conclusión, acaban echándole en cara que tiene un demonio dentro (Jn 7, 20).

\subsubsection{La ceguera de los sabios no es fatal: algunos se abren a la revelación de Jesús}

Es importante anotar que la contraposición entre la gente sencilla, los insignificantes, y los entendidos, los jefes, no es automática ni fatalista.

Marcos $(12,28-34)$ presenta el caso de un maestro de la ley que se ha quedado tan complacido de la respuesta que dio a los saduceos (el grupo dominante rival), haciendo ver el sentido de la resurrección y su base escriturística, que se atreve a hacerle la pregunta más importante en la discusión entre los grupos dirigentes, la que versa sobre el principio en torno al que se estructura todo el sistema religioso judío. Jesús le responde que se estructura alrededor del amor a Dios y al prójimo, es decir, no alrededor de los sacrificios y ofrendas del templo. El maestro se siente muy complacido de la respuesta de Jesús y la glosa. En este caso se da una coincidencia, en dos temas cruciales, entre la postura del maestro y la de Jesús. Este lo reconoce así cuando, como conclusión y despedida, le dice: "Tú no estás lejos del reino de Dios" (Mc 12, 24).

Sin embargo, aunque es cierto que se daban algunas afinidades significativas entre algunos maestros, singularmente de la escuela de Hillel y Jesús, hay que reconocer que no es fácil que un maestro reconocido en Israel dé el paso de reconocer públicamente a Jesús. Eso entrañaba, nada menos, que desmarcarse del establecimiento, un costo demasiado oneroso. 
El caso de Nicodemo, que desarrolla a través de tres etapas el cuarto Evangelio, lo evidencia. El primer episodio se abre con la iniciativa del maestro de ir de noche donde se hospeda Jesús a expresarle su reconocimiento: "Maestro, sabemos que Dios te ha enviado para enseñarnos porque nadie puede realizar los signos que tú haces si Dios no está con él” (Jn 3, 2). El maestro universitario, para decirlo anacrónicamente, el doctor reconocido por la academia, que en la sociedad judía era también autoridad política, reconoce al maestro carismático, ungido directamente por la sabiduría de Dios. Es un reconocimiento discreto, pero personal. Equivale a llamarlo colega e incluso a reconocer su enseñanza. Como se ve, es un paso atrevido y consciente. Sin embargo, Jesús le responde que no son colegas, que él tiene que hacerse su discípulo. Nicodemo le contesta que es una exigencia desmedida: nacer de nuevo como discípulo a su edad y con sus méritos parece una petición imposible. ¿Cómo iba a mezclarse él con esos galileos impetuosos y simples? Jesús insiste en que él es el portador del Espíritu, frente a la ley que él representa, que es solo sabiduría para vivir esta vida. El encuentro no tiene conclusión (Jn 3, 1-21).

El segundo episodio tiene lugar en una situación apretada: precisamente, cuando los jefes, que habían decidido apresar a Jesús, insultan a los guardias por no haberlo traído. Los jefes les habían dicho: “Es que alguno de nuestros jefes o de los fariseos ha creído en él?" (Jn 7, 48). Y entonces interviene Nicodemo: "AAcaso nuestra ley permite condenar a alguien sin haberlo oído para saber lo que ha hecho? Los otros le replicaron: ‘'También tú eres galileo? Examina las Escrituras y verás que de Galilea no ha salido jamás un profeta'. Terminada la discusión, cada uno se marchó a su casa" (Jn 7, 51-53). Nicodemo no dice ninguna palabra en defensa específica de Jesús, solo enuncia un principio jurídico que ellos, que se jactan ante los guardias de conocer las Escrituras, estaban contraviniendo. Sus colegas reaccionan indignados porque presienten que esa defensa abstracta de la juridicidad esconde una simpatía hacia el acusado; pero no pueden responder a su argumento y desisten de apresar a Jesús y se va cada quien por su lado. Es claro que Nicodemo ha arriesgado demasiado y que en adelante va a estar fichado por sus colegas como discípulo encubierto.

El tercer episodio es el salto a dar la cara por Jesús. Acontece cuando al parecer se ha cerrado ya el caso de Jesús con esa muerte ignominiosa, que equivale a una completa desautorización. Cuando al parecer no tiene ya sentido ocuparse de su persona, Nicodemo se presenta con unos treinta kilos de perfumes para embalsamar al reo. Junto con otro sanedrita, el rico José de Arimatea, que es quien pide permiso al procurador romano para enterrarlo en un sepulcro y no en la huesera común, "se llevaron el cuerpo de Jesús y lo envolvieron con vendas de lino bien empapadas en los aromas" (Jn 19, 40). Cuando las autoridades judías, juzgando a Jesús un falso profeta, lo han entregado a las autoridades romanas para que sea crucificado como Mesías político, estas dos 
autoridades, un gran terrateniente y un reconocido maestro de la ley, deciden hacerle un homenaje y enterrarlo con honores en un sepulcro nuevo. Queda claro que la decisión supone desautorizar la ejecución y las razones alegadas. Si, como parece, Pilato lo condenó, a pesar de comprobar su inocencia, por la connivencia con los poderes locales, es normal que lo autorizara como un pequeño desquite indirecto. Pero para las autoridades judías, de las que formaban parte estos dos hombres, ese homenaje era una deslealtad inadmisible.

Gracias a Dios, en la historia, las conductas no están predeterminadas por los papeles sociales; pero sí es cierto que estos entendidos y poderosos que aceptaron la revelación de Dios en Jesús tuvieron mucho que perder cuando tomaron esa decisión; aunque suponemos que la tomaron no como un deber, como una carga pesada, sino con alegría íntima por haber arriesgado todo para poseer el tesoro que colma la vida.

\subsection{4. ¿Los discípulos pertenecen a los sabios o a la gente sencilla?}

Es hora de preguntarnos dónde quedan los discípulos en esta contraposición. Ya dijimos, al hacer la exégesis del texto, que la mayoría de los autores piensan que los discípulos pertenecen al colectivo de los sencillos y que eso opinaron los sanedritas de ellos la primera vez que comparecieron en el sanedrín, tras la curación del paralítico que pedía en la puerta hermosa del templo. Para ellos, eran idiotas e iletrados.

Vamos a preguntarnos ahora cómo reaccionan ante la revelación progresiva del modo de realizarse el reinado de Dios, que va llevando a cabo Jesús.

Un texto muy sintomático en el que ciertamente reaccionan como la gente es el de la tempestad calmada. Jesús había estado hablando todo el día desde una barca y está completamente agotado. Por eso, en vez de desembarcar para continuar hablando con los que lo requieran, les pide que pasen a la otra orilla. Le ponen un cojín en la popa y con la brisa de la tarde se queda profundamente dormido. El viento arrecia y no se dan abasto para achicar el agua que se les mete. Cuando ven que la barca está en peligro de hundirse, despiertan a Jesús no para que se ponga a salvo, sino para que los salve a ellos. Jesús calma el viento y les increpa: "¿Por qué se dejan llevar por el miedo? ¿Es que no tiene fe? Pero ellos seguían aterrados, preguntándose unos a otros: ‘Quién es este que hasta el viento y el mar le obedecen?" (Mc 4, 41). En la reacción de los discípulos se mezcla el pánico ante la muerte próxima y el sobrecogimiento ante ese dominio soberano, sobre todo de él mismo para estar sereno en ese trance, y después, de los elementos.

Es un dominio sobrehumano ejercido humanamente, o, mejor, lo sobrehumano consiste en esa plenitud inalcanzable de humanidad, uno de cuyos aspectos es, según el relato del Génesis (1,26.28), el dominio sobre los elementos, como 
manifestación de la imagen de Dios que es el ser humano. Jesús, que es prototipo de la humanidad, es decir, la Imagen perfecta de Dios, a cuya imagen hemos sido creados los seres humanos, nos supera infinitamente en humanidad. De este dominio no despótico, sino simbiótico, de la naturaleza es expresión este acontecimiento.

Los discípulos se abren a él, pero no pueden asimilarlo. Jesús se les escapa y el que se les escape será motivo de dolor mutuo, pero también será un ingrediente fundamental de su adhesión a él. Como gente sencilla, saben estar ante el misterio sin pretender reducirlo racionalísticamente.

El caso de la transfiguración, en cambio, no sigue esta pauta, sino la de los entendidos. Los discípulos, por boca de Pedro, habían confesado a Jesús como el Mesías: el ungido por el Espíritu para liberar a su pueblo. Pero lo concebían de un modo nacionalista. Así lo dicen los discípulos de Emaús: "Un profeta poderoso en obras y palabras delante de Dios y de todo el pueblo. Nosotros pensábamos que él sería el liberador de Israel, pero nuestros jefes lo entregaron para que lo condenaran a muerte y lo crucificaron" (Lc 24, 19-21).

Por eso, cuando, como respuesta a la confesión de Pedro, Jesús les dice que va a acabar a manos de las autoridades, Pedro se lo lleva aparte y lo reconviene por lo que cree falta de fe en el poder de Dios que posee. Jesús le responde dos cosas: la primera, que el que interpreta la voluntad de Dios es él, no Pedro. Pedro tiene que ponerse atrás, en el puesto del discípulo. Y segunda, que ese criterio suyo es diabólico, porque busca apartarlo del designio del Padre. Y llamando a la gente, les dice que si alguien quiere seguirlo, que no crea que va al éxito; por el contrario, tiene que estar dispuesto a cargar con su cruz, que era la pena más atroz. Él no prometía éxito, sino fecundidad histórica, porque quien se afinca en la autoafirmación absoluta, pierde la vida; mientras el que sale de sí y la arriesga, la gana (Mc 8, 29-37). Los discípulos no se abrieron al mensaje de Jesús: no veían gloria, sino ignominia en el camino que les proponía Jesús.

Por eso seis días después, sube a un monte con tres de ellos y allí Dios, para que comprendan que el camino de Jesús sí está lleno de gloria, les permite verlo como él lo ve. Y lo ven, en efecto, lleno de la gloria de Dios. Pero Pedro no quiere aceptar que esa es la gloria del camino y le propone quedarse allí, a pesar de que Jesús estaba hablando con Moisés y Elías del éxodo que iba a tener lugar en Jerusalén: de su salida ignominiosa de este mundo y de su rehabilitación definitiva por parte de Dios. "Es que no sabía lo que decía porque estaban aterrados" (Mc 9, 6).

Como la vista de la gloria de Jesús no ha logrado el objetivo de convencer a los discípulos de la propuesta de Jesús, desaparece la visión y el monte queda henchido de la nube densa de la presencia de Dios. Se oye la voz del Padre que pide que escuchen a su Hijo. Pero ellos se inhiben y mientras bajan solo le 
preguntan si no tiene que venir antes Elías a ponerlo todo en orden; se entiende que matando a los romanos y a los colaboracionistas judíos. Tampoco ahora saben lo que dicen. Y no saben porque no quieren abrirse a la propuesta de Jesús de no imponerse a la fuerza, sino dar de sí hasta dar la propia vida, incluso a sus enemigos.

Como se ve, no reciben la revelación de Jesús ni del Padre porque se aferran a sus concepciones, a su versión de la salvación, que incluye pasar todo tipo de trabajos, pero para ocupar los primeros puestos en el reino sagrado y terreno del Mesías. Es la mentalidad de los entendidos, de los dirigentes, que quieren dominar el designio de Dios que incluye su estatus de privilegio.

\subsection{La sentencia en el conjunto de la doctrina de Jesús}

Pasemos ahora a estudiar la enseñanza de Jesús para ver qué lugar ocupa en ella la sentencia sobre la revelación del reinado de Dios a los sencillos y el ocultamiento a los entendidos.

\subsubsection{Recibir a los insignificantes es señal de tenerse por insignificante y eso es ser grande. Es condición para entrar en el Reino}

Comenzaremos por una sentencia a los discípulos que empalma con lo último que hemos tratado: "Los discípulos comenzaron a discutir quién de ellos era el más importante. Pero Jesús, que se dio cuenta de lo que estaban pensando, tomó a un niño, lo puso a su lado y les dijo: 'El que recibe en mi nombre a este niño, a mí me recibe, y el que me recibe a mí recibe al que me envió. Porque el más insignificante de ustedes, ese es el más importante" (Lc 9, 46-48). Hemos insistido en que sencillo equivale a insignificante y el niño en su sociedad era el más insignificante de todos. Ellos, que se las daban de enterados en la configuración del reino de Dios, que lo asimilaban a poder incontrastable, sagrado y justo, miraban hacia arriba, hacia los primeros puestos. No tenían ojos para mirar hacia abajo, hacia los insignificantes. Eran insignificantes por su origen y así los tenían los jefes; pero ellos se creían llamados a grandezas humanas y por eso buscaban ser considerados como los más importantes. Jesús les dice paradójicamente que el más importante para él y para su Padre es el más insignificante. Como hemos insistido, es la expresión de la preferencia divina anclada en el misterio, en que Dios es así.

El Evangelio eclesiástico de Mateo lleva esta cuestión a la comunidad. Por eso en la recepción de ese pasaje, Jesús les pide lo siguiente: "Les aseguro que si no se convierten y se hacen como los niños, no entrarán en el reino de los cielos" $(18,3)$. En este pasaje, sabios y sencillos no son categorías inamovibles ni papeles sociales, sino actitudes internas. Por eso los discípulos, que caminan en la dirección de los entendidos, de los que se las saben todas y dominan a los 
demás, son requeridos por Jesús para que se pasen al bando de los sencillos, de los que se saben insignificantes y están por eso abiertos a Dios y a los demás. Si no cambian de dirección vital, no podrán entrar al Reino. La razón es que solo el que se tiene a sí mismo como insignificante puede estar ante Dios como un niño: sabiéndose sin derecho a nada y confiado en su misericordia; y también solo quien se tiene como insignificante ante los demás se abre a ellos dispuesto a recibir y a dar, según lo pida la situación.

En otro pasaje de Lucas, precisamente en el momento tan emotivo y revelador de la cena de despedida, los discípulos se ponen una vez más a discutir sobre quién de ellos era el mayor. Jesús les responde de un modo personalizado: "¿Quién es mayor? ¿El que está a la mesa o el que sirve? ¿No es el que está a la mesa? Pues bien, yo estoy en medio de ustedes como quien sirve" $(22,27)$. La contraposición es entre el mayor y el insignificante, que es una de las acepciones de la gente sencilla. Jesús les hace ver que si participan de la lógica dominante, tienen que concluir que Jesús es el menor entre ellos porque les solía servir la mesa. Como para ellos, ciertamente, Jesús es el mayor, si quieren seguir pensándolo coherentemente, tienen que cambiar de mentalidad.

El mayor es servido y el menor sirve. Para Jesús la grandeza humana consiste en servir voluntariamente. Servir con libertad puede acontecer incluso cuando la ubicación social demanda el oficio de servir. En cambio, desde la lógica establecida, que es la de los que se tienen por los mayores, la aspiración humana es subir incesantemente para descargarse en otros y recargarse en ellos. A eso aspiran los discípulos. Ellos son, sin duda, pequeños; pero están dispuestos a pasar cualquier trabajo con tal de llegar por fin arriba, a los mayores puestos.

Jesús, como enviado del Padre, revela a estos pequeños que quieren desmarcarse de ese estatuto que los empequeñece ante sus ojos y ante los demás, que es bueno que quieran crecer lo más posible, pero que eso no equivale a dejar de ser sencillos y asumir el papel de los poderosos. Ser más es poner a producir los dones que Dios da a cada uno para provecho de los demás (Mt 25, 14-30). Ser más es, pues, servirlos; y el mayor será entonces el que más sirva. El mayor es el propio Jesús, que se ha hecho servidor de todos: "Porque el Hijo del Hombre no ha venido a que lo sirvan, sino a servir y a dar su vida en rescate por muchos" (Mc 10, 45).

Así, pues, ser sencillo, ser insignificante, tiene dos acepciones: ante todo, un estatuto social y una condición cultural, es decir, unas determinadas dotes o, mejor, la carencia de algunas dotes muy estimadas en esa cultura; y en segundo lugar, una elección que cualifica a todo el ser hasta el punto de definirlo en cierto modo. Lo mismo podemos decir de la acepción de importante y entendido. Estas dos acepciones son las que contempla la bienaventuranza de los pobres en la doble recepción de Lucas y Mateo. 


\subsubsection{La mayor revelación a los insignificantes: el reino de Dios es para ellos}

Empecemos por la recepción de Lucas $(6,20)$. Del insignificante, como ubicación social, del pobre, del despreciado, afirma Jesús como parte de su Evangelio que el Padre ha querido revelarles el misterio del Reino, que, como hemos insistido, equivale a entregárselos. Por eso los pobres, que por serlo son desdichados, pasan a ser felices cuando escuchan esta bienaventuranza y creen en ella. Los pobres, en la bienaventuranza de Lucas, son los que no tienen cómo tener y, por eso, por esa carencia estructural, que no pocas veces es privación injusta, se sienten disminuidos y minusvalorados. Estos pobres, por carencias antropológicas y culturales o por falta de oportunidades, son en todo caso la masa que no cuenta, los insignificantes. Pues bien, a estos que no pueden valerse por sí mismos y que no tienen valedor, el Dios de Jesús les asegura por su medio que ya no pueden decir que están solos porque él es su Papá materno que se hace cargo de ellos y los trata como a hijos queridísimos.

Ya insistimos en que Jesús sacramentalizó con su vida esta preferencia de su Padre. Jesús convivía sobre todo con pobres. Al haber renunciado a su casa, familia y oficio, era uno de ellos y vivía como ellos en la calle y como ellos dependía de otros para su subsistencia. Pero no era solo un carente. Desde esta condición social, él fue la persona más cualitativa y entregada a los demás. Pero, insistamos en ello, nos enriqueció con su pobreza. No tenía cosas para dar y por eso nos dio de sí hasta el punto de darse completamente a sí mismo. Lo hacía como expresión de su fraternidad. Él era nuestro hermano mayor, nuestro primogénito. Pero lo era en el aspecto de uno de tantos, de uno de los pequeños. Pues bien, al hacerse nuestro hermano nos entregaba a su Padre; en su fraternidad nos asociaba a su filiación.

Por eso, al decir que los pobres eran dichosos porque de ellos es el reino de Dios, sabía lo que decía porque lo decía desde dentro: él era ante todo el destinatario de la bienaventuranza; y los demás sabían a qué atenerse, porque podían ver que no era una sentencia abstracta sin ningún contenido analítico, ya que estaban captando cómo en los signos de Jesús y en su presencia acogedora estaba aconteciendo Dios como salvación para ellos. En la entrega fraterna de Jesús se les estaba entregando Dios como misericordia, como Padre con entrañas de madre.

Los pobres que creen en esta propuesta de Jesús, aunque no haya cambiado su entorno, sí pueden afrontarlo de un modo enteramente distinto porque su valedor es el mismísimo Dios. Aunque con la llegada de Jesús sí ha cambiado su entorno, porque él es su valedor en el sentido más literal de la palabra, no el que les da cosas, sino el que los pone a valer. Si estos insignificantes aceptan la paternidad de Dios y se relacionan con él como hijos suyos verdaderos, no solo no están ya solos, sino que esta relación los enriquece, ya que poseen el mayor tesoro posible: una persona, nada menos que la de Dios, que se les ofrece como Padre, 
que les da esperanza y los moviliza de manera que de la relación les van naciendo actitudes humanizadoras y capacidades. Estos pobres van dejando de serlo a nivel antropológico y ya solo lo serán en sentido social, es decir, en cuanto que se les niegan oportunidades.

Es patente la correlación entre la paternidad maternal de Dios y la fraternidad de Jesús. La persona humana de Jesús que les da esperanza y los promueve liberando sus mentes y haciendo brotar actitudes nuevas es la expresión (revelación como acontecimiento) de la entrega de Papá Dios, que proclama Jesús, que quiere reinar sobre sus corazones y su ambiente como Padre de misericordia inagotable. De este modo, hace creíble Jesús lo que proclama. Como se ve, la bienaventuranza a los pobres es la máxima expresión de la preferencia de Dios por esos seres humanos a los que se les revela entregándoseles como Padre materno ${ }^{21}$.

Con esta bienaventuranza casa la evangelización de los pobres como una de las concreciones de la misión que entraña la unción mesiánica. Aunque más que una de las concreciones diríamos que es uno de los armónicos de la única misión de restablecer la vida menoscabada ( $\operatorname{Lc} 4,18-19)$. Por eso la proclamación de la buena nueva a los pobres es también una de las señales que Jesús ofrece a los enviados del Bautista, que mandó a dos de sus discípulos a preguntar si era el que tenía que venir o tenían que esperar a otro $(\operatorname{Lc} 7,22)^{22}$.

De esta sentencia, "los pobres son evangelizados", es decir, reciben la buena noticia de que Dios les ha dado su Reino, se ha entregado a ellos como su Padre maternal, se infiere que el Evangelio, como plasmación inspirada de la vida y misión de Jesús, pertenece a los pobres, es decir, que ellos tienen derecho a que se les proclame y que, por tanto, no basta ni con que se cobijen como menores de edad en la institución eclesiástica ni que se les entreguen medios para vivir, ni que se los capacite para hacerlo por cuenta propia. Tienen derecho a que se les proclame de una manera explícita y fehaciente, es decir, de manera que ellos puedan hacerse cargo de lo que implica esa proclamación: que en Jesús de Nazaret Dios se ha convertido en su Padre maternal y quiere que ellos vivan con la confianza y la dignidad propia de sus hijos.

Lucas, que trae esta recensión de la bienaventuranza a los pobres, la aclara y complementa con los ayes por los ricos, por los que ríen, por los satisfechos,

21. "Por esto los pobres son llamados bienaventurados y a ellos se les promete el Reino, no por ser mejores, ni porque el sufrimiento sea bueno y así merezcan el cielo, sino porque ellos son los que comprenden el misterio del Reino gracias a la revelación del Padre y ellos son los destinatarios privilegiados de este proyecto del Padre que Jesús revela" (V. Codina, "La fe de los insignificantes", óp. cit., p. 94).

22. Barreto insiste en que no es una de las señalas, ya que todas las demás tienen como sujeto a los pobres, pues son manifestaciones extremas de pobreza (J. Barreto, "Reinado de Dios y revelación divina", óp. cit. pp. 23-28). 
por aquellos a los que por su importancia económica y social la gente rodea de un halo de consideración (Lc 6, 24-26). El sentido de estos versículos estriba en que los ricos, al vivir satisfechos tanto por el disfrute de sus riquezas como por la consideración social que reciben, no se cuidan ni de tener a Dios como Padre ni de tener a los demás como hermanos. El disfrute les ha empequeñecido el corazón y les ha impedido vivir humanamente. Como se ve, no es Dios quien causa su desgracia; son ellos los que se la fraguan al poner su vida en sus riquezas.

Hay que aclarar que los ayes no expresan amenazas, sino lamentaciones. A Jesús le duele que sea así y por eso se lamenta públicamente. Lo hace no solo para manifestar su dolor por la pérdida de esos hermanos suyos, sino para que los que lo escuchen puedan cambiar de actitud, se hagan sencillos y no se pierdan.

\subsubsection{Estar ante Dios dependiendo como un pobre de su misericordia}

Con esto pasamos a la recensión de Mateo $(5,3)$. Hay que decir que es secundaria, pero que no hay por qué excluir que esa versión sea también recuerdo fidedigno de la predicación de Jesús. Cuando decimos secundaria no estamos quitándole relevancia, sino afirmando que viene en segundo lugar.

Lo primero es la preferencia del Dios de Jesús por un determinado tipo de personas y su determinación de entregarse a ellas como su Padre materno. Una preferencia absolutamente gratuita, independiente de la solvencia moral de los insignificantes ${ }^{23}$.

Lo segundo es la voluntad de Dios de que todos, en primer lugar los propios insignificantes, pero también ciertamente todos los demás, incluidos los ricos y entendidos, estemos ante él como insignificantes, es decir que, siendo conscientes de que nunca podremos llegar a él por nuestras propias virtualidades y méritos, nos mantengamos en su presencia pendientes tan solo de su benevolencia. Estos son los pobres de espíritu: los que tienen ante Dios la misma actitud que tienen los pobres ante quienes pueden darles lo que ellos no pueden procurarse: son los que tienen espíritu de pobres, los pobres de espíritu. Estos pueden decirle al Señor lo que dice el salmo y suena tan duro a nuestros oídos emancipados: "Como están los ojos de los esclavos fijos en las manos de sus señores / como están los ojos de las esclavas fijos en las manos de sus señoras / así nuestros ojos

23. Así lo expresa con toda claridad la Tercera Conferencia General del Episcopado Latinoamericano, reunida en 1979 en Puebla: "Los pobres merecen una atención preferencial, cualquiera que sea la situación moral o personal en que se encuentren. Hechos a imagen y semejanza de Dios para ser sus hijos, esta imagen está ensombrecida y aun escarnecida. Por eso Dios toma su defensa y los ama. Es así como los pobres son los primeros destinatarios de la misión y su evangelización es por excelencia, señal y prueba de la misión de Jesús" (1142). 
están fijos en el Señor / esperando su misericordia. / ¡Piedad, Señor, piedad / que estamos hartos de desprecios / que estamos demasiado hartos del sarcasmo de los insolentes / del desprecio de los orgullosos!” (123, 2-4).

Por supuesto, quien ante Dios se tiene realmente como un pequeño, quien sabe que eso es en verdad y no alguien importante y con derechos, tampoco se sentirá con derechos ante nadie ni se sentirá grande ante sus propios ojos. Vive lo que dice el salmo: "Señor, mi corazón no es engreído ni mis ojos altaneros / no persigo grandezas ni prodigios que me superan. / Calmo y silencio mi anhelo / como un niño junto a su madre / como un niño junto al Señor" (131, 1-2).

Como se ve, de acuerdo con la oración que estamos analizando, Dios revela su reino a los sencillos y por eso quiere que todos lo sean, y, en concreto, que los entendidos e importantes dejen de serlo para que también puedan recibirlo como Padre materno. Dios quiere que todos tengamos esta actitud, ante todo porque es la actitud de quien vive en la realidad, que es que nadie es nada ante Dios y, sin embargo, todos podemos tener esperanza de que su amor misericordioso nos acoja con benevolencia.

A todos está abierta esta posibilidad, pero todos tenemos que hacer un camino para llegar a hacerla nuestra. Los insignificantes tienen que salir de su postración y su resignación fatalista por su situación y abrirse a la esperanza de que Dios es su Padre maternal; y los que se tienen por entendidos y poderosos tienen que salir de su autoafirmación orgullosa y su autocomplacencia, así como de su insensibilidad respecto de los que ellos consideran como nada. Todos tenemos que hacer camino; pero es verdad que es más fácil salir del abatimiento y abrirse a la esperanza que salir del autocentramiento y la autocomplacencia. Por eso los pobres tienden a sentir la bienaventuranza de los pobres de espíritu como una buena nueva, mientras que los que se tienen por grandes tienden a sentirla como una mala noticia porque los relativiza radicalmente, aunque sea para darles el reino: a Dios como Padre y a los demás como hermanos.

\section{Sentido de esa sentencia en América Latina hoy}

El contenido de la oración de Jesús de Nazaret que venimos estudiando adquiere en nuestra época unos matices inusitados y un relieve mayor que cuando fue pronunciada por Jesús; más todavía, una trascendencia que no ha tenido en la historia de la humanidad que conocemos.

\section{1. ¿Quiénes son en esta época globalizada los entendidos y los insignificantes?}

En primer lugar, nos preguntamos quiénes son hoy los sabios y entendidos y cómo operan. Vivimos en la sociedad del conocimiento, en el sentido preciso de que el conocimiento científico-técnico es el mayor capital, y para que lo sea 
en el sentido estricto de las relaciones de producción, se contrata al que lo posee y se patentan sus producciones; así, el conocimiento se convierte en propiedad privada no de individuos, sino, ordinariamente, de corporaciones mundializadas.

Este es uno de los métodos por los que estas corporaciones acumulan más poder que los Estados. Los otros, relacionados también con el conocimiento, son la planificación centralizada (lo que ellas pregonan que no tienen que hacer los Estados) y los contactos confidenciales (casi al margen o positivamente al margen de la ley), que proporcionan datos que no tienen los demás, y las influencias que de ahí se derivan.

Correspondientemente, los sencillos, los insignificantes, son los que no poseen este tipo de conocimiento, elevado a la condición de paradigma de todo tipo de conocimiento. Estas personas son consideradas como las que no cuentan, como irrelevantes para el progreso del mundo, aunque posean otros conocimientos humanísticos e incluso lo que solía llamarse en la sociedad tradicional sabiduría de la vida ${ }^{24}$.

Si esta es la situación mundial, en América Latina las élites, tanto latinoamericanas como las del mundo globalizado, nos hacen saber que como región andamos bastante retrasados respecto del estándar mundial y que por eso somos bastante irrelevantes en el escenario globalizado. Es verdad que algunos países van dando pasos firmes en esta dirección, pero se requieren sacrificios mucho más profundos y generalizados que los actuales para que nos pongamos a la altura de la hora mundializada.

\subsection{Discernimiento de esta situación}

Estamos de acuerdo en que tenemos que crecer mucho más en capacitación científico-técnica y en que este desarrollo humano demanda enormes dosis de sacrificio. Pero estamos en desacuerdo en que se subordine todo lo demás a este objetivo, es decir, que se persiga de un modo absoluto, sin reparar en los costos humanos, y, lo que es peor, teniendo como sujetos a las actuales élites, en vez de iniciar un proceso sostenido de capacitación de toda la sociedad, desde

24. Víctor Codina caracteriza así a los nephioi de América Latina: "Podríamos decir que nepioi se refiere a la gente sin importancia, que no cuenta, que no sabe ni puede, el grupo de personas que en América Latina E. Galeano llama 'los nadies' y que Gustavo Gutiérrez califica como 'insignificantes'. Podemos, pues, traducir los nepioi por insignificantes, que incluye a pequeños, ignorantes, pobres, mujeres, indígenas y afroamericanos, ancianos, excluidos y marginados sociales... los que no significan nada para los grandes y poderosos de este mundo. Son los mismos que Pablo llama débiles, plebeyos, despreciables, locos a los ojos del mundo, pero que han sido escogidos por Dios para confundir a los sabios y poderosos de este mundo (1 Cor 1, 26-31)" (V. Codina, "La fe de los insignificantes", óp. cit. p. 93). 
la primaria hasta la universidad y las escuelas técnicas superiores, haciendo una discriminación positiva a las masas que actualmente se encuentran en una desventaja casi insuperable.

Pero, sobre todo, no estamos de acuerdo en poner todo el esfuerzo en los medios descuidando los fines. El pavoroso vacío humano del mundo desarrollado, que no solo carece de proyecto histórico, sino que justifica esa ausencia alegando que el proyecto se lo tiene que hacer cada uno y que el contenido de la democracia tiene que ser meramente procedimental, de manera que salvaguarde y potencie los proyectos de cada asociado, es consecuencia previsible y objetable de este planteamiento. Nos hacemos personas en relación con los demás; asumirnos, por tanto, como individuos que carecen de vínculos obligantes es no solo negarse a reconocer la realidad, sino resignarse a no ser personas.

Pero es más grave todavía el destino de estos individuos cuando se dejan determinar por las coordenadas de la dirección dominante de esta figura histórica, porque las corporaciones, para que su planificación y las inversiones consiguientes sean lo más seguras posible, vuelven adictos a los individuos con la publicidad, de manera que los que sienten la compulsión de consumir tengan que plegarse a sus ofertas de trabajo para conseguir dinero para adquirir esas mercancías y, de modo general, para llevar ese estándar de vida que estiman indispensable para ellos. De esta suerte, el proyecto, supuestamente personal, resulta en gran medida inducido, y lo pretendidamente personal queda reducido a elegir dentro de un menú previamente elaborado. Así, los que se la pasan escrutando las oportunidades en el mercado de trabajo y las mercancías, los entendidos, son individuos unidimensionalizados y hasta cierto punto programados por otros. Individuos tan constreñidos por las reglas de juego dominantes, que son incapaces de concebir que otro mundo es posible. Hasta ahí llega la ceguera de los entendidos.

No basta, pues, con superar la discriminación, aunque es indispensable y entraña un reto descomunal, porque, como es bien sabido, nuestra región es la más desigual del mundo, y los países que han elevado notablemente el producto interno bruto (como Brasil, Chile, Colombia y México) no han logrado disminuir esta brecha social.

Es también imprescindible cambiar el modelo de desarrollo, de manera que el desarrollo humano prime sobre el desarrollo científico-técnico. Gracias a Dios, voces crecientes vienen reclamándolo en el Primer Mundo. Este debate debe ganar terreno en la opinión pública y es indispensable que se dé en los medios universitarios como parte sustantiva del proyecto institucional, ya que si las universidades acaban por adaptarse a los requerimientos de las corporaciones, al reducirse a proveedores de sus requerimientos de material humano, perderán toda su trascendencia y serán parte del problema y no de la solución. 


\subsection{Peculiaridad de la situación latinoamericana}

Pero además nosotros tenemos otra problemática peculiar: sincronizar la hora mundial y la hora latinoamericana. Porque solo cuando logremos esta sincronización estaremos en condiciones de entrar en la globalización no de modo apendicular, como sucede hasta el presente, sino con peso y perfil propios y con capacidad de aportar.

El problema es que esta problemática es totalmente desconocida por nuestras élites. El hecho al que tenemos que prestar atención es que estamos entrando en la tercera época de nuestra región, después de la época amerindia y de la época de los españoles y lusos, tanto europeos como americanos, devenida finalmente de los occidentales americanos. Esta tercera época en la que entramos se caracteriza por el reconocimiento del carácter multiétnico y pluricultural de la región en un estado de justicia e interacción simbiótica. Tenemos que admitir que la modernización, en el sentido preciso de que las élites occidentales americanas estuvieran dispuestas a compartir el poder con gente de cualquier etnia, con tal de que abandonaran su cultura y asumieran la occidental americana, ha llegado a su fin, porque las distintas etnias desean adquirir los bienes civilizatorios del occidente mundializado, pero no para dejar sus culturas, sino para vivirlas sin ningún complejo y de modo que tengan vigencia.

Los sabios y entendidos del establecimiento latinoamericano no tienen ojos para ver este proceso; están ciegos para lo que no sea la cultura científico-técnica globalizada. No solo eso: han decidido impedir que esta tercera época se consolide y están dispuestos a pagar cualquier precio para lograrlo. Por eso, para ellos, un indicio fehaciente de la insipiencia de las masas es ese empeño que tienen en promover sus culturas populares, parejo al de adquirir los bienes civilizatorios del Occidente.

\section{Asunción de la sentencia por parte de los cristianos latinoamericanos}

\subsection{Cómo se revela Dios, es decir, cómo mueve su Espíritu a los sencillos}

¿Cómo suena hoy en América Latina la oración de Jesús que estamos analizando? Nuestra respuesta contundente sería que el Espíritu del Dios de Jesús impulsa a esta gente sencilla, a estos tenidos como insignificantes, en su esfuerzo simultáneo por capacitarse en los bienes científico-técnicos del Occidente mundializado y por hacer de nuestra América multiétnica una región en la que se reconozcan las culturas populares (indígenas, afrolatinoamericana, campesina y suburbana), al lado de la criolla tradicional (que se expresa sobre todo en las instituciones) y la occidental mundializada, que son actualmente las dos culturas dominantes. Este carácter pluricultural tiene que expresarse en los símbolos globalizadores y en las instituciones. 
Así como en tiempos de Jesús Dios reveló a la gente sencilla de Galilea que él pasaba por Jesús sacándolos de su postración y movilizándolos, de tal manera que el motivo por el que las autoridades decidieron acabar con él fue su ascendiente entre las masas, que iba en la dirección de superar su minoridad, liberar sus mentes y, de este modo, cancelar el dominio ideológico que tenían los maestros de la ley y los fariseos sobre ellas; así hoy, su Espíritu las mueve en la dirección de desarrollarse humanamente desde sus culturas, asumiendo también los bienes civilizatorios de la mundialización, y en la de reivindicar el lugar que les corresponde en cada país y en la región como tal.

Por tanto, los poseedores de los conocimientos científico-técnicos y los que manejan las instituciones nacionales se oponen al movimiento del Espíritu cuando no secundan este movimiento histórico, por absolutizar su propio paradigma y para conservar su dominio secular sobre ellas.

Gracias a Dios, la división entre entendidos y sencillos no es (en esto hemos insistido) fatal, y por eso gente minoritaria, pero altamente significativa, de cultura criolla e incluso de cultura mundializada, apoya inteligente y decididamente este proceso en alianza horizontal y mutua con gente de etnias y culturas populares. Es importante anotar que apoyan no solo por moral, sino como ganancia para ellos. Es decir, que la solidaridad de estos grupos minoritarios, pero no excepcionales, no entraña una relación unidireccional y de arriba hacia abajo con los sectores populares, aunque se ejercite de un modo generoso y humilde, sino una relación horizontal y mutua. Poco a poco, empieza a superarse el esquema ilustrado ${ }^{25}$, y estos profesionales competentes y generosos están aprendiendo a entablar un diálogo de horizontes, un diálogo intercultural, superando el esquema anterior en el que la única cultura considerada dinámica y con futuro era la occidental, que fungía de paradigma indiscutible.

\subsection{Cómo se revela Dios, es decir, cómo actúa la fe en Jesús, en los sencillos}

Desde el punto de vista cristiano, esta preferencia de Dios por los sencillos e insignificantes se realiza de un modo general por la acción del Espíritu de Jesús en ellos, una acción contrastada por el seguimiento de otros espíritus y por la resistencia, a veces, al de Jesús, pero, en resumidas cuentas, una acción victoriosa. Esto es así porque si donde no hay condiciones para vivir logran vivir y vivir humanamente, es que lo hacen en obediencia al Espíritu dador de vida y, más específicamente, al Espíritu de Jesús de Nazaret. En efecto, Jesús de Nazaret es paradigma eximio de humanidad, es decir, el modelo más excelente de ella; pero es además prototipo de humanidad, es decir, para nosotros los cristianos, es el molde en el que todos somos creados: la Imagen perfecta de

25. P. Trigo, El cristianismo como comunidad y las comunidades cristianas, Convivium Press, Miami, 2008, pp. 194-213. 
Dios a cuya imagen hemos sido creados. Esto que proclama nuestra fe es también la experiencia de no pocos de ellos que, cuando no pueden más, sienten en sí unas fuerzas superiores a ellos que los sostienen en vida, que los empujan hacia adelante y los ayudan a mantener su dignidad, así como a estimular su sentido práctico y su sentido de la oportunidad para encontrar cómo vivir ${ }^{26}$.

Más específicamente, tenemos que decir que los insignificantes que han sido evangelizados, es decir, que han escuchado como dirigida a ellos personalmente la bienaventuranza de los pobres y han creído en ella (los que Ellacuría llamaba pobres con espíritu ${ }^{27}$ ), son el corazón de la Iglesia, lo más vivo y creativo de ella, y por otra parte son también quienes en sus ambientes mantienen la convivialidad, siembran comunidades abiertas y vivas, y ayudan a que la comunidad humana en la que viven conserve su calidad de humana y se articule.

Cualquiera que no esté ciego tiene que admitir que estos pobres son quienes mantienen la fe en América Latina y, más generalmente, la humanidad que nos caracteriza, a pesar de todo. Así, pues, Dios se sigue revelando hoy, por su Espíritu y por su Hijo, a los sencillos, a los insignificantes, en América Latina y ellos siguen acogiendo esa revelación que se da en acontecimientos históricos, y, más radicalmente, posibilitando la vida negada.

Pero también tenemos que reconocer que la eclosión y el florecimiento de la Iglesia latinoamericana se debieron a que un grupo minoritario, pero altamente cualificado, de gente ilustrada que supo captar los requerimientos de Dios en esta hora y responder creativamente a ellos, tanto hombres (y más aún mujeres) de Iglesia como profesionales, decidió entrar en la casa del pueblo, es decir, entrar no solo a sus casas físicas, sino a su cultura y aliarse con ellos.

El que estos entendidos apostaran por los pobres, hasta el punto de hacerse gente sencilla, es un acontecimiento trascendental para la Iglesia latinoamericana e incluso para la Iglesia universal y para la región como tal. Desde la pléyade de obispos que llevaron a su pueblo y se dejaron llevar por él, hasta la multitud de religiosas que se insertaron en barrios y caseríos y comunidades indígenas, encarnándose (como se decía con toda congruencia teológica) en esos

26. Así lo expresa Codina con gran sencillez y hondura: "A la pregunta de Gustavo Gutiérrez 'dónde van a dormir los pobres', podemos añadir otro interrogante: ¿por qué no se suicidan los pobres, sino que luchan por la vida, se casan, tienen hijos, esperan un mañana mejor, compran flores y celebran fiestas? La respuesta es profunda y sencilla al mismo tiempo: El Señor, que les revela los misterios del Reino, suscita en ellos una gran esperanza, sienten que 'Diosito' siempre les acompaña" (V. Codina, "La fe de los insignificantes", óp. cit. p. 94.; el punto está explanado en las pp. 95-96).

27. I. Ellacuría, Conversión de la Iglesia al reino de Dios, Sal Terrae, Santander, 1984, pp. 76-77. Para el contexto, ver pp. 68-79. 
medios, o, en verso de Martí, echando su suerte con los pobres de su tierra; hasta los profesionales que dinamizaron tantos proyectos de promoción, concientización y organización popular; y hasta los teólogos que dieron congruencia teórica a todo ese movimiento fundamentándolo en el Evangelio y sistematizándolo.

Al analizar las bienaventuranzas de Lucas y de Mateo, insistíamos en que lo primero de todo es la predilección de Dios por los insignificantes, una predilección que, si la corresponden, los dinamiza de modo que dejan de ser antropológicamente pobres y solo lo son por falta de oportunidades, por las reglas de juego injustas y estáticas. Pero que además él nos pide a todos, en primer lugar a los propios pobres, pero también a los que no lo son, incluso a los que se tienen por entendidos y poderosos, que estén ante él con espíritu de pobres. Quienes aceptan esta propuesta dejan de ser, a sus propios ojos, gente que se las sabe todas y tiene derecho a todo y, por tanto, desea ser tenida así también por los demás. Estos pobres de espíritu están ya en condiciones, y no menos en disposición interna, de aliarse con los pobres para reestructurar las reglas del juego de modo que sean buenas conductoras de la fraternidad de las hijas e hijos de Dios ${ }^{28}$.

\section{Conclusión}

La sentencia de Jesús es expresión de lo que sucedió en su ministerio y de lo que todavía sucede mayoritariamente hoy, pero no expresa el deseo más hondo de su corazón ni del de su Padre. Este iría en la dirección de un encuentro histórico entre los pobres y los pobres de espíritu, es decir, la alianza entre los que no tienen cómo tener y por eso son tenidos como insignificantes, y ordinariamente ellos se tienen por tales, por un lado; y los pobres que se dejan llevar por el Espíritu, los que han recibido y aceptado la buena nueva de la bienaventuranza a los insignificantes y los entendidos que han optado por la sencillez, por el otro. Este fue el acontecimiento del que nació la Iglesia latinoamericana, con peso

28. Castillo sintetiza así su estudio sobre Jesús y el pueblo: "Las convicciones determinantes de la vida no se integran (no las integramos), en nuestras pautas de conducta, por vía del 'conocimiento'. Porque tales convicciones no son un 'saber' que se puede asimilar por el estudio o se puede encontrar en los libros. Las convicciones determinantes de la vida se integran en nosotros por el camino de la 'sintonía' con los seres humanos. Y aquí está, me parece a mí, el secreto de todo lo que, en el fondo, nos dicen los Evangelios sobre la cercanía de Jesús a las multitudes y la respuesta de estas a su 'mensaje' (...) Y entonces resulta comprensible aquello de que el Padre del cielo 'ha escondido estas cosas a los sabios y entendidos', mientras que 'se las ha revelado a la gente sencilla", (J. M. Castillo, "Jesús, el pueblo y la teología. I", óp. cit., p. 138). Así ha seguido aconteciendo en la historia; pero también hay que decir que en nuestra Iglesia latinoamericana hubo y hay todavía sabios y entendidos que cultivan esa sintonía que hace fecundas sus vidas y su saber. 
propio y conciencia de sí, y sobre todo del que nació una gran esperanza para nuestros pueblos y una renovada conciencia de su misión para nuestras élites. Esta es también la propuesta de la teología de la liberación, que enfatiza que en esta junta mutuamente salvadora la primacía debe corresponder, de acuerdo a la predilección de Dios, a la gente sencilla que, en medio de su inmensa debilidad y de sus pecados, vive la santidad primordial ${ }^{29}$ de vivir del Espíritu dador de vida, ya que ellos no tienen condiciones para vivir. En esta alianza con ellos dan su verdadera talla los sabios y entendidos, a la vez que corrigen las desviaciones a las que los lleva su estatus como un plano inclinado.

Tratando de decir con mis palabras lo que está en el fondo de esta contraposición, diría que los sabios y entendidos de los que habla Jesús son los que conocen los códigos del orden establecido y pueden manejarlos para su conveniencia y la de sus empleadores. Este conocimiento les da una gran ventaja y se convierte en una fuerte tentación. Lo que pide Jesús es que esta ventaja se transforme en responsabilidad respecto de todo el colectivo social y especialmente de los que no poseen estas claves. No es fácil una conversión tan radical para el que se identifique con este saber que en el fondo es solo un saber manejarse en lo establecido. El verdadero sabio, que se esfuerza por situarse honradamente ante la realidad, sí encuentra que esta responsabilidad que le pide Jesús va en la línea de ese hacer justicia a la realidad que dinamiza su vida y, por eso, puede comprender que, aunque asumirla entrañe costos crecientes, es un reclamo de lo más auténtico de sí mismo, que se corresponde con el clamor, muchas veces sordo, de esos insignificantes que demandan aliados para salir de su postración.

Esta es también la invitación personal de mi Señor Jesús que dinamiza mi pobre vida y que la llena de alegría por lo que acontece en los encuentros con los sencillos, alegría que me da fuerzas para caminar, aunque es de noche, como decía Juan de la Cruz y reinterpreta Gustavo Gutiérrez para nuestra América como noche oscura de la desigualdad tenazmente mantenida, de la injusticia, de la insensibilidad. Esta vida es la que arroja la luz que trato de plasmar con el mayor rigor y honradez posibles en mis escritos, con la ayuda imprescindible de los métodos y conocimientos científico-técnicos. Esta es, finalmente, la invitación a ustedes que ha guiado estas palabras como ofrenda agradecida a su generosidad. Muchas gracias.

29. J. Sobrino, Fuera de los pobres no hay salvación, Trotta, Madrid, 2007, pp. 103-105; ver, además, pp. 21-24, 26, 75-105. 